PART ONE

AN EMERGENT ENTERTAINMENT INDUSTRY 
Philip Yampolsky - 9789004261778

Downloaded from Brill.com04/26/2023 09:37: ๑๑AM via free access 
CHAPTER TWO

\title{
MUSIC ON DUTCH EAST INDIES RADIO IN 1938: REPRESENTATIONS OF UNITY, DISUNITY, AND THE MODERN
}

\author{
Philip Yampolsky
}

The period in which increasing integration was to have come about [as proponents of 'Indisch nationalism' or 'Indisch citizenship' hoped] - the first half of [the 2oth] century - instead witnessed a rapidly increasing segmentation of colonial society. (Van Doorn 1983:6)

They were like two planets moving along their own orbits, in a very confined universe. If merely to stay on track, it was logical and imperative that each of them, the Eastern as much as the European radio, work strenuously on building up and shielding their own wholeness or, at least, the appearance of it. (Mrázek 2002:184)

Mangkunegara's broadcasts of his palace musicians [on the Solosche Radiovereeniging station, SRV] ... brought 'palace art' to any listeners with access to a receiver, at a time where other princely houses - particularly in Yogyakarta - were also 'democratizing' their arts by making them available outside the palace. Live broadcasting added another dimension, though, by at once localizing something modern and modernizing something local. Mangkunegara VII's broadcast of live gamelan music was a totally modern act. (Lindsay 1997:108)

This chapter is an initial report on a project I began years ago as a complement to my research on gramophone recording in Indonesia in the latecolonial era. The purpose of the gramophone research is to learn about the musical life of the Dutch East Indies (DEI) in that era - with respect both to the musical features of the various genres and to how music functioned in society, what it meant to people to perform it or listen to it or buy records of it. ${ }^{1}$ This complementary research on radio broadcasting reveals a side of things we cannot see from studying the record industry.

1 Portions of my work on gramophone records have been published in Yampolsky 2010 and 2011. This is a much-expanded version of a paper presented at a KITLV workshop on 'Popular Music in Twentieth-Century Southeast Asia,' held in Jakarta on 10-11 January 2011. I want to thank my research assistant, Tiur Manalu, who spent countless hours copying out radio listings and photographing newspaper articles for me; Bart Barendregt, Peter Keppy, and Henk Schulte-Nordholt for a fellowship enabling me to pursue radio matters

(C) PHILIP YAMPOLSKY, 2014.

This is an open access chapter distributed under the terms of the Creative Commons Attribution-Noncommercial 3.0 Unported (CC-BY-NC 3.0) License. 
Radio was more strongly conditioned by its physical location than were records. To make new records, a recording company could send its engineers on tour to cities across Java, ${ }^{2}$ and if it wanted to record musicians who did not live along the tour's route, those performers could be brought to the engineers. For radio, however, it was too expensive and impractical to bring musicians to the cities from afar, especially for repeated broadcasts; instead, radio stations were largely dependent for live broadcasting on local musicians, or on broadcasts relayed from other stations in other cities.

On the other hand, radio was more flexible than the gramophone industry in exploring new talent. A gramophone recording represented a considerable investment in artists' fees, engineers' fees, shipment of master recordings abroad for manufacture, and actual production costs, plus shipment of the finished records back to the DEI for sale and distribution to retail outlets. For this reason, recording companies, though they had a constant need for new product, were cautious in recording untried performers. Radio, however, could afford to give unknowns a chance, and in order to develop new talent stations solicited and attended to audience input. For example, Soeara Nirom, the program guide for the governmentcontrolled NIROM network's Oostersche (Eastern) Programma, stated in November 1937 that 'many of our Arab listeners in Surabaya' had requested that a certain gambus group, the Gamboes Orkest Alhambra, perform on air, and accordingly NIROM would give the group a trial broadcast (pertjobaän) on 18 November 1937. Then in February 1938 the guide announced that audience reaction to the trial broadcast had been good, so now Alhambra would be broadcast regularly. In October 1939, the same publication reported that in response to the trial broadcast of another gambus group (Gamboes Orkest Assoffa), NIROM had been inundated with letters and reports from all corners of the colony. ${ }^{3}$ It cost the radio station

at the KITLV in Leiden and for comments on the workshop presentation; and, as usual, Alan Feinstein, Jennifer Lindsay, Henk Maier, and Andrew Weintraub for their incisive and illuminating comments, questions, and criticisms, even if sometimes I am too mulish to profit by them.

${ }_{2}^{2}$ Nearly all recording in the DEI was done in Java, with the exception of the Odeon/ Beka tours to Bali in 1928 and 1929 and some recording in West and North Sumatra in the second half of the 1930 .

3 Soeara Nirom 1937e, 1938b, 1939d. More on letters to NIROM: at the beginning of 1937, Soeara Nirom said it was receiving 'statements of satisfaction with our broadcasting' - 100 letters and postcards a month - from all over: Palembang, Balikpapan, Medan, Malang, Payakumbuh, Manado. And in November 1939 NIROM announced a new policy, to give five minutes of airtime every day to letters from listeners. Only letters of general interest would be answered on air; others would be replied to by letter 'as usual' (Soeara Nirom 1937b, 1939f). 
virtually nothing to do a proefuitzending (trial broadcast); performers would have been happy for the opportunity to go on the air, and if a new group was a failure it simply was not invited back.

Thus research into radio broadcasting uncovers musicians who did not make it onto record, and it situates music in a localized and day-to-day temporal context as gramophone records cannot. Those are the concerns of the first part of this chapter: what radio research can tell us about Indonesian music near the end of the colonial era. But this research also allows us to consider the position of radio and radio music in the great issues that were in the air in the 1930s: modernity, nationalism, the relations between colonizer and colonized, and the development of an Indonesian (rather than narrowly ethnic, local, or religious) consciousness. Radio's relation to these issues is the focus of the second part of the chapter.

\section{On the Air}

Both record and radio research are shaped (one could say deformed) by the fact that they must be for the most part indirect. Some collections of records exist, but I estimate that no more than $30 \%$ of the gramophone records produced for the DEI before 1942 can be found in collections, and those collections are scattered around the world. Even so, record researchers are better off than those who work on radio: broadcasts were in those days wholly ephemeral, and there is no retrieving them today. Studying both radio and gramophone records, then, requires us to work with secondary sources: catalogues and advertisements for records, program guides for broadcasts. And program guides are even harder to find than records. That is why this chapter focuses on 1938 - not because that year was particularly momentous, but because it is the year for which I could find complete runs of program guides for the largest number of stations.

\section{Live vs. Recorded Music}

In this chapter I map the live music broadcast on five radio stations for the twelve months of 1938. Live music on a sixth station is summarized but not tabulated. ${ }^{4}$ First, though, a defining question needs an answer: why live music?

4 Technically this sixth was not a station but a programme, the Westersche Programma, of the same broadcasting network (NIROM) that produced two other programmes, the Oostersche Programma for West Java and a different Oostersche Programma for Central and East Java). Since all three NIROM programmes had different content, it is convenient to treat them as separate stations. I should explain a convention I follow in this chapter: I 
Radio discourse in the 1930s assumes that listeners prefer live music to gramophone records. An increase in the amount of live broadcasting is always touted by the radio stations as an improvement. A station in Surakarta (Solo) assures its listeners,

[With a subsidy from the government-sponsored radio network, NIROM] we will be able to improve [memperbaiki] our programme by adding live music [menambah levende muziek]. Not only twice a week, but maybe three or four times a week or even every day we can send out klenengan [gamelan music], alternating with [other genres of music and theater accompanied by music, such as] kroncong and kethoprak, wayang orang, etc. (DarmoKondo 1934b)

\section{A station in Batavia says,}

The board always thinks about and works toward increasing the ratio of true broadcasting to broadcasting of gramophone records, ${ }^{5}$

and a year later the same station announces with pride that it now airs

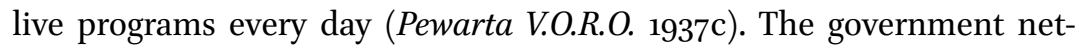
work, at the start of its fourth year of operation, says that a reorganization will allow it to 'improve our programming, increasing live broadcasting by more than 50\%' (Soeara Nirom 1937a); and four years after that, looking back over seven years of broadcasting, it observes:

At the start we had to rely on music from gramophone records, but little by little we reached the point where records were only used to fill up the time between two live broadcasts, of which there are now very many. So the situation is reversed, and live broadcasting is now the mainstay of our programme. ${ }^{6}$

In 1941, after the government has ceded control of broadcasting to 'Eastern' audiences to a federation of private (i.e. non-government) stations, a

use programme (or its Dutch equivalent, programma) for an overall broadcasting design or structure, such as the Western and Eastern programmes of NIROM (or the BBC's Third Programme), and program for an individual broadcast, such as a kroncong group's program on such-and-such a date. We could consider a station's published program guide to be a guide to the overall programme, but in fact it was used to tell listeners what programs would be broadcast when, so I call it a program guide rather than a programme guide.

5 'Senantiasa memikir-mikirkan dan mengoesahakan akan membesarkan penjiaran sebetoelnja ditimbang dengan penjiaran plaat-plaat gramaphoon' (VORO Jubileumnummer 1936:9).

6 'Kalau kita pada permoelaan siaran kita teroetama sekali mesti bekerdja dengan moesik dari piring gramofoon, tetapi lambat-laoen moesik dari piring gramofoon ini oemoemnja hanja dipakai oentoek mengisi waktoe jang terloeang antara doea siaran hidoep jang banjak benar didalam programma kita. Djadi sebaliknja siaran-hidoep itoelah sekarang jang mendjadi siaran-oetama didalam programma kita' (Soeara Nirom 1940e). 
newspaper article criticizes the new regime with a long list of complaints, including:

Sometimes the schedule for one night - indeed, often for two nights in a row - has no live kroncong or gamelan music, even though these two kinds of music are the centerpieces of the broadcasting programme. They ought to be in the schedule every night. (Pewarta Soerabaia 1941a)

Nevertheless, radio needed gramophone records. In an essay written at the beginning of official broadcasting, K.W.L. Bezemer, the General Director for Broadcasting at NIROM, the government-approved network, wrote that 'although the public generally expresses a preference for live performance,' when it comes to 'what the English call "high-brow" music' (he uses the English term), NIROM must depend on records, because there are not enough skilled performers of European classical music in the DEI (De N.I.R.O.M.-Bode 1934a). (Besides, he continues, with new technological advances in recording, recordings sound as good as live music, and when we start receiving here the new automatic record changers from Europe, which allow a long work to be heard without interruptions to change the disc, even the most spoiled listeners will have little to complain about.) While how to please devotees of classical music seems a specialized problem, it points up one of the virtues of gramophone records for any station: they could be played when live performers were not available. But of course a station had to renew its stock from time to time. VORL, broadcasting to the 'native' audience in Bandung, complained in 1939 that its listeners were bored with all the records VORL owned or could borrow from its members, and for lack of new records VORL could not, unlike other stations, broadcast in the morning hours. ${ }^{7}$ (Presumably live musicians - who might have day jobs - could not be counted on for morning broadcasts.)

Another virtue of the gramophone record was that it was cheap compared to live performers: one had to pay musicians every time they played on the air, but a one-time purchase bought a record the station could play indefinitely. An inventory statement from VORO in Batavia shows that in 1937 that station had 377 records in inventory, and it couples this information with a statement that 2208 hours of gramophone music were broadcast in that year (Pewarta V.O.R.O. 1938). If, for the sake of a rough calculation, we assume that all the records it broadcast were the ones in its own inventory, that each side of each record was three minutes long,

\footnotetext{
7 Berita VORL 1939. According to its 1938 inventory statement, VORL owned 705 playable (bruikbaar) records and another 309 unplayable (onbruikbaar) that were presumably either broken or worn out (Berita VORL 1938b).
} 
and that the station played all the records the same number of times, then each side of each record would have been played nearly 60 times in the course of the year.

Table 2.1, put together from disparate sources, sketches the proportions of live music and recorded music broadcast in the DEI. (Some details of the table, such as the relation of VORO to NIROM, will become clear later

Table 2.1. Broadcasting of live and recorded music (including theater) on DEI radio, shown as number of hours (yearly) and as percentages of total music broadcasting (TM).

\begin{tabular}{|c|c|c|c|c|c|}
\hline & $\begin{array}{l}\text { Live } \\
\text { music } \\
\text { (hours) }\end{array}$ & $\begin{array}{l}\text { Live } \\
\% \text { of } \\
\mathrm{TM}\end{array}$ & $\begin{array}{l}\text { Gramo } \\
\text { records } \\
\text { (hours) }\end{array}$ & $\begin{array}{l}\text { Gramo } \\
\% \text { of } \\
\mathrm{TM}\end{array}$ & $\begin{array}{l}\text { Total } \\
\text { music } \\
\text { (hours) }\end{array}$ \\
\hline \multicolumn{6}{|l|}{ NIROM WESTERSCHE* } \\
\hline 1935 & & $32 \%$ & & $68 \%$ & $100 \%$ \\
\hline 1937 & & $18 \%$ & & $82 \%$ & $100 \%$ \\
\hline 1939 & & $27 \%$ & & $73 \%$ & $100 \%$ \\
\hline 1940 & & $24 \%$ & & $76 \%$ & $100 \%$ \\
\hline \multicolumn{6}{|c|}{ NIROM OOSTERSCHE $1936^{* *}$} \\
\hline Batavia (VORO) & 831 & $40 \%$ & 1227 & $60 \%$ & 2058 \\
\hline Bandung & 935 & $46 \%$ & 1115 & $54 \%$ & 2050 \\
\hline Surabaya & 1050 & $51 \%$ & 998 & $49 \%$ & 2049 \\
\hline \multicolumn{6}{|l|}{ VORO (BATAVIA) } \\
\hline $\begin{array}{l}1935 \text { (VORO for } \\
\text { NIROM)**** }\end{array}$ & 784 & $47 \%$ & 885 & $53 \%$ & 1669 \\
\hline $\begin{array}{l}1936 \text { (VORO for } \\
\text { NIROM)** }\end{array}$ & 831 & $40 \%$ & 1227 & $60 \%$ & $205^{8}$ \\
\hline $1937(\text { VORO alone })^{* * *}$ & 1004 & $31 \%$ & 2208 & $69 \%$ & 3212 \\
\hline $1938(\text { VORO alone })^{* * *}$ & 1007 & $30 \%$ & 2296 & $70 \%$ & 3303 \\
\hline
\end{tabular}

\section{Notes:}

* Figures for the NIROM Westersche Programma come from Witte 1992:29 for 1935 and 1939, and from Witte 1998:113 for 1937 and 1940. They are apparently based on tabulations of one month's broadcasts for each year.

** Figures for the NIROM Oostersche Programma in 1936 come from Pewarta V.O.R.O. $1936 \mathrm{~b}$ and $1936 \mathrm{c}$ and cover two four week periods (19 July-15 August and 13 September-10 October 1936). The figures have been averaged and extrapolated to cover a full year.

*** These figures (except 1936, for which see the ** note) come from VORO sources and cover a full year, requiring no extrapolation. For 1935: VORO Jubileum-nummer. For 1937: Pewarta V.O.R.O. 1938. For 1938: Pewarta V.O.R.O. 1939a. 
in this chapter.) It is apparent from the table that the amount of recorded music was considerably higher in broadcasting to the Western (Westersche) audience. It stands to reason that with some 215 Indonesians, Chinese, and 'other Asiatics' for every one European in Java and Madura (and over 250:1 for the whole colony), there would have been a bigger pool of musicians available to play live for the Eastern audience.

I still have not fully answered the question of why this chapter concentrates on live music. Partly the reason is that, as I said at the start, it is meant to complement my research on gramophone records. Since I have discussed or will discuss elsewhere the character and circumstances of recorded music in the DEI - including, naturally, the records played on the radio - the present study can concentrate on what was unique to radio, namely the live broadcasting. Another reason is that, as we have seen, both the stations and the audiences believed that (in VORO's words) 'true broadcasting' was live; it was what the medium was meant for. And a third reason is suggested by the quotation from Jennifer Lindsay I have taken as an epigraph: live broadcasting was an inherently modern thing to do in the closing years of the colonial era. I will return to the modernity of radio at the end of this chapter.

\section{A Brief History of Radio in the DEI}

Radio begins in the DEI as the hobby of the wealthy - amateur enthusiasts, first in Batavia, then in other main cities, and mostly if not entirely

8 For other general accounts, see Sedjarah radio di Indonesia 1953 and Wild 1987, and for detailed considerations of specific topics, see Lindsay 1997 (private radio before and after Independence) and Witte 1998 (NIROM, with emphasis on the Westersche Programma). Mrázek 2002 includes a meditation on radio's place in the imagination of the colony. Like the present chapter, Takonai 2007 examines music programming, but for different time periods and with different points of focus. (See footnote 31) Another work making use of radio program guides, though not focused primarily on music, is Wiryawan 2011, which concentrates on the private ketimuran stations, particularly SRV. (I thank Jennifer Lindsay for bringing this book to my attention.) Wiryawan and I differ in focus and disagree in interpretation: dualistically, he sees the private radio stations as motivated by a heroic ideological and nationalistic commitment to protecting Indonesian or Eastern culture from Western poison, and NIROM as opportunistically imitative of the private stations, motivated by imperatives of commercial competition; whereas I see all the ketimuran stations, including NIROM, as broadcasting the same material (much of it already Western, despite the ketimuran rhetoric) and using the same formats, with NIROM - if only because it had more money, better equipment, and a broader network - coming the closest (though still not very close) to reflecting and honoring Indonesia's cultural diversity. Wiryawan seems determined to champion the private stations and disparage NIROM, and partly because of this bias and partly because of incomplete information 
within the segment of the population designated European. ${ }^{9}$ The first organized radio group was the Bataviase Radiovereeniging (BRV), which in 1925 began broadcasting (in Dutch) from the Hôtel des Indes in Batavia. Operating expenses were covered by the members of the vereeniging (association) themselves. A more commercial venture was initiated a few years later by the Nederlands-Indische Radio Omroep Maatschappij (Dutch East Indies Radio Broadcasting Company), known as NIROM, incorporated in Amsterdam in December 1928 with capital from three investors: Radio-Holland, the Philips group, and Maintz \& Co. The aim of the venture was to develop broadcasting from Holland to the DEI, and within the DEI itself.

In September 1930 a proposal from NIROM was debated and ultimately approved in the Volksraad (People's Assembly) in Batavia, and in January 1933 the government of the DEI granted NIROM a ten-year concession to conduct broadcasting operations in the colony. Private radio groups like BRV were allowed to stay on the air, but none had the resources to compete with NIROM's powerful transmitters. A year after the concession was granted, NIROM began broadcasting.

Despite the threat (and, from 1934, the fact) of NIROM, small radio groups continued to emerge in the DEI throughout the first half of the decade. In 1930, Mangkunegara VII, officially the 'younger' of the two princes of Surakarta (Solo), gave a small transmitter to a kunstkring (arts circle) of aristocratic art patrons, who used it to broadcast gamelan concerts from the Mangkunegara's palace (the Mangkunegaran) every 35 days. At that time there were no more than 20 radio receivers in Solo. In early 1933 a group of people affiliated with the Mangkunegaran was formed to upgrade the transmitter and plan regular broadcasts. Describing itself as a perhimpunan (collective), this group was formally established on 1 April 1933, under the name Solosche Radio Vereeniging (Solo Radio Association, SRV), but it did not begin broadcasting until eight or nine

there are inaccuracies in his treatment of several key topics, such as NIROM's ketimuran programming, the nature and availability of gramophone records in the DEI, and NIROM's relation to SRV. (In order, I think, to protect SRV's image, he mentions the subsidy NIROM paid to VORO but not the one it paid to SRV from 1934 through 1937 and perhaps beyond; see footnote 21 here.) Nevertheless, Wiryawan's is a well-researched, though slanted, study of radio in the DEI.

9 The term covered persons born in Europe of European parents, persons born in the Indies of European parents, and recognized children of unions between a Dutch father and an Asian mother. (Curiously, Japanese were also classified as Europeans. Chinese and Arabs were not.) For more on this topic, see Van der Veur 1955 (ch. 2), and Van Marle $195^{1-52 .}$ 
months later. ${ }^{10}$ SRV was the first of the stations devoted to what would come to be called siaran (or radio) ketimuran, 'broadcasting of an Eastern character' ('Eastern broadcasting' for short). These particulier or 'private' stations broadcast primarily in Indonesian (Melayu) and concentrated on content of interest to pribumi, Eurasians, and Chinese-Indonesians. ${ }^{11}$

The next private ketimuran association to appear, known as MAVRO (standing for Mataramsche Vereeniging voor Radio Omroep, 'Mataram [=Yogyakarta] Association for Radio Broadcasting'), was formed by a group of aristocrats from the Yogyakarta courts in February 1934. Other ketimuran radio groups emerged later that year: one in Batavia that was first called VORL (for Vereeniging van Oostersche Radio Luisteraars, 'Association of Eastern Radio Listeners') but changed its name (in late December 1934, after the agreement with NIROM was negotiated) to VORO (Vereeniging voor Oostersche Omroep, 'Association for Eastern Broadcasting'); ${ }^{12}$ one in Surabaya called CIRVO (Chineesche en

10 There is a discrepancy in SRV sources regarding the date of the first broadcast. In a speech at the official opening of SRV on 24 January 1934, Sarsito Mangoenkoesoemo, the chairman of SRV, says the initial trial broadcast occurred on 14 December 1933, and further broadcasts were made every night thereafter (Darmo-Kondo 1934a). In a 1939 article Sarsito again says the first broadcast was in mid-December 1933 (1939:183). But the station's 1936 anniversary book, the SRV gedenkboek ([1936]:6), says it took place on 5 Januari 1934, which it specifies was 'Saptoe Kliwon ... pada sorenja, hari malam Akad Legi' (that is, it was Saturday in the seven-day week and Kliwon in the five-day 'market week,' and the time was the eve of Sunday-Legi; this latter detail fixes the day as Saturday, not the eve of Saturday, which in European reckoning would still be Friday). In fact, 5 January 1934 was a Friday; if the first broadcast occurred on Saturday-Kliwon, the date was 6 January 1934. Wiryawan $(2011: 86,182)$ repeats the Gedenkboek's date of 5 January 1934. The date given by Sarsito was a Thursday, not a Saturday.

11 Pribumi: 'native Indonesians'; Inlanders or Inheemschen in colonial parlance. The term pribumi was understood to exclude persons of Chinese ancestry, no matter how long their families had been in Indonesia. Eurasians, in this context, means persons of mixed European and Indonesian descent without European status. Colonial society distinguished between those who qualified as Europeans under the law (as in footnote 9; Van der Veur reserves the term 'Eurasian' for this group), and those who did not, typically because they were not recognized by their European fathers or because it was their mother who was the European parent. In this chapter, context should make it clear whether I am referring to Eurasians classified as Europeans, to Eurasians classified as pribumi, or to all persons of mixed European-Asian ancestry, regardless of classification. Van der Veur (1955:22) observes that 'legally, culturally and socially [Eurasians who qualified as Europeans] were set apart from their brethren of mixed descent "on the other side of the fence". The one stream of mixed descent constantly fought hard to be accepted as Dutch citizens in practice; the other stream diffused almost instantly into the indigenous population, quickly becoming an integrated part of it.' Both propositions in the last sentence are, I think, overstated. There was surely duality, ambivalence, and divided loyalty on both sides of the line.

12 The name was changed because the association thought the original name implied that only Asians could become members, whereas 'there are many groups other than Easterners [golongan diloear Ketimoeran] who are devoted to Eastern broadcasting' 
Inheemsche Radioluisteraars Vereniging Oost Java, 'Association of Chinese and Native Radio Listeners of East Java'); and one affiliated with the Kraton Solo (the 'older' Solonese princedom), called SRI (Siaran Radio Indonesia, 'Indonesian Radio Broadcasting'). SRI was not a perhimpunan, since it had no subscribers; it described itself instead as a 'philanthropic service' of the Kraton to disseminate Javanese high culture. Still more ketimuran groups started in the next years: VORL (Vereeniging voor Oosterse Radio Luisteraars, 'Association for Eastern Radio Listeners') in Bandung at the end of 1935, and Radio Semarang in 1936.

Although they will not be discussed at any length in this chapter, one should note that there were also private radio groups broadcasting primarily to a Europe-oriented, Dutch-speaking audience. On the model of the phrase siaran ketimuran, these can be called siaran kebaratan (Western broadcasting). ${ }^{13}$ Four such groups formed the Omroep Vereeniging in Java (Broadcasting Association of Java) and in January 1935 began publishing a joint program guide, the Radio-Bode. The four groups in the association were: BRV (Bataviase Radio Vereeniging), PMY in Bandung, RVMJ in Semarang, and ARVO in Surabaya.

The salient distinction between NIROM and the private radio groups is precisely that the private groups were private, responsible only to their membership, while NIROM answered to the government. ${ }^{14}$ It is less relevant to stress, as one writer has, that NIROM was a profit-making venture and the private groups were not. The commercial aspect of NIROM should not be overemphasized: NIROM did not make its money from advertising, but rather from a government-administered compulsory license fee levied on radios, known as the luisterbijdrage (listening contribution) or omroepbijdrage (broadcasting contribution). ${ }^{15}$ In return for the concession, the government demanded that NIROM's broadcasts reach the whole of Java within one year from the start of broadcasting and the entire colony within three years. NIROM was also responsible for ensuring that

(Pewarta V.O.R.O. 1935c). Undeterred, the radio group that formed in Bandung in late 1935 (see Berita VORL 1938 a for this date) took the name VORO had discarded.

13 Soeara Nirom sometimes uses this term (e.g. Soeara Nirom 1938a).

14 The private groups were engaged in what today in the United States would be called 'listener-supported radio.'

15 In 1934 the luisterbijdrage for NIROM was $f_{3}$ a month. By 1938 it had come down to fi.50 a month, still a significant sum. At the beginning of January 1939 it went down again a talen to fi.25. The license covered only NIROM. Listeners to the other ketimuran stations were expected - implored - to become members and make monthly contributions: in 1938 , the contribution for an ordinary member (there were higher, more expensive grades as well) was fi a month for VORO, VORL, and MAVRO, fo. 50 for SRV. 
its broadcasts not conflict with the interests of the State, the laws of the land, public order, and good morals. ${ }^{16}$

NIROM's first official broadcast took place on 1 April 1934. Radio technology did not yet permit signals from one studio, even with relays, to reach all the way from Batavia to East Java, so NIROM had to set up two studios, one in Batavia and one in Surabaya, and broadcast separate programmes from each. At the start, broadcasting was only in Dutch and served almost exclusively the Europe-oriented audience, with an hour or two per week for Asian gramophone records; this broadcasting was known as the Westersche (Western) Programma.

Two months later, at the end of May, NIROM announced in its program guide, De N.I.R.O.M.-Bode, that Indonesian (Inlandsche) and Chinese listeners had requested that NIROM make more room for Eastern (Oostersche) music in its broadcasts. 'But to fulfill this request,' the announcement continued,

would be a difficult matter, because it doesn't seem possible to take time from the programme we already have and use it for Eastern music. It is certain that Eastern music is not much liked by the European public, just as the Indonesian public does not much like European music. The number of registered listeners to NIROM is at present around 6200, of whom circa 1250 are Natives, Chinese, and Foreign Asiatics. ${ }^{17}$ Given this ratio, it would be unfair of NIROM to split its programming between European and Eastern music. The only solution that would be fair for all parties is to set up separate transmitters to broadcast European and Eastern music (De N.I.R.O.M.-Bode 1934b). ${ }^{18}$

16 This is the gist of Article 6, paragraph 6 of the Gouvernements Besluit (governmental decree) no. 38, which granted the concession to NIROM on 30 December 1932. (The decree, first published in the Javasche Courant on 10 January 1933, is photographically reproduced in Witte 1998:190-194.) In keeping with Article 6, the government required the private ketimuran stations - but not apparently NIROM - to submit scripts of all spokenword material to officials of the Post, Telegraph, and Telephone Service for review before broadcast. This must have been an onerous requirement for comedians, dhalang (puppeteers), and theater troupes, all of whom typically worked without a script. I have come across one documented incident where the rule was applied: in March 1937 a scheduled broadcast on VORO by the Chinese Opera troupe Hiap Kioen Hie had to be cancelled, because the script had not been sent to the government 14 days beforehand for approval (Pewarta V.O.R.O. 1937 b, 1937 d). A similar incident involving a tayuban broadcast on SRV (in itself rather surprising) is mentioned in an August 1938 newspaper article (Sin Tit Po 1938), but I do not have the details.

17 The official figure for radio licenses at the end of 1933 (see Table 2.2a) was 8,58o, far above the figure NIROM gives here. I have no explanation for the discrepancy.

18 'Dari pihak publiek bangsa Indonesia dan Tionghoa banjak datang permintaän kepada kita, soepaja lebih banjak diloeangkan tempat dalam programma boeat lagoelagoe Timoer. Akan memenoehi permintaän itoe adalah satoe perkara jang soesah djoega, sebab tidak moengkin rasanja boeat mengambil waktoe lagi dari programma jang soedah ada itoe boeat lagoe Timoer. Soedah tentoe lagoe Timoer tidak begitoe disoekai oleh publiek bangsa Eropah, seperti djoega publiek bangsa timoer djoega koerang menjoekai 
Soon there were more complaints from the non-European listeners, including an aksie-vergadering (protest meeting) in Batavia on 10 June 1934, in which listeners complained that NIROM's idea of Oostersche programming was to broadcast only a few hours a week, only gramophone records, and only at times when few people were listening (Pewarta V.O.R.O. 1935b). Apparently these protests were mainly on behalf of West Javanese listeners, since at the time of its official opening NIROM had already worked out an arrangement to pay a subsidy to SRV in Solo to relay live broadcasts to audiences in Central Java. ${ }^{19}$ Beginning in January 1935 NIROM gave a further subsidy to VORO, the private ketimuran group in Batavia, to organize NIROM's live broadcasting to Batavia's Oostersche listeners. ${ }^{20}$ NIROM continued its subsidy to SRV and made a similar arrangement with MAVRO in Yogyakarta; in Surabaya and Bandung, NIROM handled the Oostersche programming itself. Thus by August 1935, when NIROM began to publish Soeara Nirom, its biweekly, Indonesian-language program guide for the Oostersche Programma, NIROM was in fact broadcasting five different Oostersche programmes: to Batavia, Bandung, Yogya, Solo/Semarang, and Surabaya.

Near the end of 1935, NIROM began to take over from VORO more of the programming for Batavia, while continuing to pay subsidies to VORO, MAVRO, and SRV. But in late 1936 NIROM announced that from January 1937 it would start to handle all of its ketimuran broadcasting itself and would therefore reduce the subsidies to the private stations. ${ }^{21}$ This decision caused an uproar among the private stations, which dreaded the loss of income and also feared that their most popular live performers would be wooed away by NIROM. The matter was raised in the Volksraad, and, surprisingly, the government's response was not to dismiss the issue but rather to suggest that the private stations should unite in a single organization to manage siaran ketimuran. This suggestion led to the formation,

\footnotetext{
lagoe-lagoe Eropah. ...' (De N.I.R.O.M.-Bode 1934c). The Dutch version of the sentence beginning (in my translation) 'It is certain' ('Soedah tentoe' in Indonesian) is: 'Het Europeesche publiek waardeert nu eenmaal slechts in geringe mate de Oostersche muziek en wij kunnen ons indenken, dat zij, die speciaal op Oostersche muziek zijn gesteld, weinig gevoelen voor het Europeesche programma-gedeelte' (De N.I.R.O.M.-Bode 1934b).

19 This subsidy arrangement was announced to the members of SRV on 1 April 1934, in a speech by the chairman, Ir. R.M. Sarsito, on the occasion of the beginning of NIROM's regular broadcasting (Darmo-Kondo 1934b).

20 The way VORO phrased this was: VORO's programs were broadcast over NIROM's transmitter, on the wavelength $190 \mathrm{~m}$. (Pewarta V.O.R.O. 1935a).

${ }^{21}$ In 1935 VORO received a subsidy of $f_{5}$ oo a month from NIROM (VORO Jubileumnummer 1936:10). In 1938 the subsidy was f20o a month (Pewarta V.O.R.O. 1939b). René Witte reports that SRV received f625 a month in 1935 and f300 a month in 1937, and MAVRO f45o in 1935 and f15o in 1937 (Witte 1998:144).
} 
in late March 1937, of the Perikatan Perkoempoelan Radio Ketimoeran (Federation of Eastern Radio Associations, known as PPRK), encompassing VORO (Batavia), MAVRO (Yogyakarta), SRV (Solo), VORL (Bandung), Radio Semarang, and CIRVO (Surabaya). (SRI in Solo was not part of the federation.) PPRK eventually - a long time later, in November 1940 - took over all siaran ketimuran from NIROM, and broadcast until the Japanese ousted the Dutch from the DEI in March 1942.

The year I focus on in this paper, 1938, sits right in the middle of this history. By 1938, NIROM was broadcasting its Westersche Programma to the whole of the DEI from Batavia, the Surabaya and Batavia Westersche programmes having been consolidated in Batavia in 1937. Taking over the ketimuran programming from the private stations had enabled NIROM to consolidate Oostersche broadcasting as well. Rather than five Oostersche programmes it was now broadcasting only two: one to West Java from studios in Batavia and Bandung, and one to East and Central Java from the studio in Surabaya. The Surabaya programme was also sent out to the 'Groote Oost' (the islands of the 'Great East' beyond Java),", and transmitters in West Java sent the Batavia/Bandung programme west to Sumatra. For the most part, NIROM was handling its ketimuran programming itself, though it relayed some broadcasts originating from one or another of the private stations, and it had an ongoing arrangement with SRI to relay gamelan performances by musicians of the Kraton Solo. At the same time, the private ketimuran stations were broadcasting to their respective regions, without substantial subsidy from NIROM. The handover of all siaran ketimuran to PPRK, to be broadcast over NIROM's transmitters but with content unsupervised by NIROM, was still two years off.

Table 2.2 situates 1938 in DEI's radio history statistically, showing how many radio licenses (conventionally equated with the number of radio sets) ${ }^{23}$ were owned in various population groups in the DEI from 1927 to $1940 . .^{24}$

22 Also to the north of Java? It is not clear whether NIROM considered Borneo part of the Groote Oost, or simply did not consider it. Administratively, Borneo and the Groote Oost were separate residencies, and they are treated as such in the DEI government's annual Indisch verslag. (See, e.g., Indisch verslag 1941 2:461.)

23 At least in theory, one could not buy a radio without paying for a license. Whether people found ways to buy unlicensed radios, or whether they could allow their license to lapse after a year and still manage to listen, is not clear to me. Citing a thesis by Budi Sulaksono (1993), Wiryawan says there were nine radio receivers in the Mangkunegaran palace compound in May 1941 (2011:84); later (2011:207) he says that they were all unlicensed, but he does not say how he (or Sulaksono?) knows this.

24 Citing the Statistical pocket book of Indonesia 1941, published in Batavia in 1947, René Witte (1998:124) gives figures that differ from those in Table 2.2. In fact, something went 
Table 2.2a. Licenses for use of radio sets in DEI.

\begin{tabular}{lcccr}
\hline Year & Europeans & $\begin{array}{l}\text { Pribumi } \\
(\text { 'Natives') }\end{array}$ & $\begin{array}{l}\text { Chinese \& Other } \\
\text { Asiatics }\end{array}$ & Total \\
\hline 1927 & & & 1,106 \\
1928 & & & 1,567 \\
1929 & & & 2,132 \\
1930 & & & & 2,464 \\
1931 & & & & 2,780 \\
1932 & & & & 4,844 \\
1933 & & & & 8,580 \\
1934 & & & & 16,875 \\
1935 & 19,020 & 4,411 & 9,088 & 27,566 \\
1936 & 25,681 & 7,259 & 12,817 & 39,028 \\
1937 & 32,756 & 12,238 & 16,863 & 54,462 \\
1938 & 39,919 & 18,173 & 20,275 & 87,909 \\
1939 & 45,039 & 25,608 & 101,868 \\
1940 & 50,054 & 31,539 & & 130 \\
\hline
\end{tabular}

Source: Indisch verslag 1941, part 2. The same figures appear in volumes of the Statistisch zakboekje voor Nederlandsch Indie (1934-1938) and in the Statistical pocket book of Indonesia 1941.

Table 2.2b. Total population of the DEI in 1930.

\begin{tabular}{lllll}
\hline & Europeans & Pribumi & $\begin{array}{l}\text { Chinese \& } \\
\text { Other Asiatics }\end{array}$ & Total \\
\hline 1930 & 240,417 & $59,138,067$ & $1,348,749$ & $60,727,233$ \\
\hline
\end{tabular}

Source: Volkstelling 1930.

Table 2.2c. Percentage of 1930 population holding radio licenses in 1938.

\begin{tabular}{lllll}
\hline & Europeans & Pribumi & $\begin{array}{l}\text { Chinese \& } \\
\text { Other Asiatics }\end{array}$ & Total \\
\hline 1938 & $16.6 \%$ & $0.031 \%$ & $0.95 \%$ & $0.12 \%$ \\
\hline
\end{tabular}

wrong with Witte's table. The figures in the Statistical pocket book (1947:145) exactly match those in Table 2.2a (which I took from Indisch verslag 1941). Witte's table unaccountably interpolates a line of figures for 1935 that are not in the Statistical pocketbook, and this interpolation throws off all the subsequent figures by one year. Thus the figures shown for 19351940 in my Table 2.2a and in the Statistical pocket book are shown in Witte for 1936-1941. 


\section{The Westersche Programma}

The following observations are based on a tabulation of 28 days of NIROM's Western programme (7 August to 3 September 1938, inclusive). The programming is dominated by the NIROM house ensembles and personnel - the Omroep Orkest (Broadcast Orchestra) and Studio Orkest directed by Carel van der Bijl, and the NIROM Quintet, directed by Boris Mariëff. Carel van der Bijl, a violinist, also leads a trio under his own name and plays chamber music with other instrumentalists. ${ }^{25}$

For the rest, there are regular broadcasts from the house orchestras at the Hôtel des Indes in Batavia and the Societeit Concordia in Bandung and broadcasts by three Hawaiian music groups and a popular-music group of unidentified specialty, the Caroline Crooners \& Avalon Boys. There are chamber music and vocal recitals by performers who may be regulars in the NIROM ensembles or perhaps local amateurs. There is one

PLAYLIST 1: EUROPEAN MUSIC. TWO BROADCASTS BY THE NIROM QUINTET ON THE SAME DAY

(a) Matinée-concert door het Nirom-Quintet onder leiding van Boris Mariëff. [Matinée concert by the Nirom-Quintet, led by Boris Mariëff].

NIROM Westersche Programma, 7 August 1938, 12:00-12:35.

[Emil] Waldteufel. Deux à deux (waltz)

Grieg. Arabic Dance (from Peer Gynt)

Mühlenau. Wiener Puppen

Sumkay. Badinerie

Zimmer. Echo der Welt

(b) Vooravondconcert door het Nirom-Quintet onder leiding van Boris Mariëff.

[Early evening concert by the Nirom-Quintet, led by Boris Mariëff.]

NIROM Westersche Programma, 7 August 1938, 18:20-19:00.

[Percy] Elliot[t]. In Sunny Spain (suite)

Johann Strauss [II]. Telegramme (waltz)

[W. C.]Powell. Fascination

Dvořák. Third Slavonic Dance

Meyerbeer-[Oscar] Fetrás. Les Huguenots (fantasie)

25 An Internet search indicates that after the war Carel van der Bijl became first violinist of the Brabant Orchestra in Holland. 
big concert, lasting two hours, by the Bataviasche Orkest-Vereeniging 'Toonkunst' (Batavian Orchestra Association 'The Art of Music'), directed by J. de Ruyter Korver, with Theo van der Pas as piano soloist; ${ }^{26}$ the program contains Mozart's Symphony no. 39, his Piano Concerto no. 23, Tchaikovsky's Serenade for Strings, two piano pieces by Chopin, and, interestingly, a 'grammophon-intermezzo.'27

PLAYLIST 2: EUROPEAN MUSIC. AN EVENING CONCERT BY THE OMROEP ORKEST

Concert door het Omroep-Orkest onder leiding van Carel van der Bijl. [Concert by the Broadcast Orchestra, led by Carel van der Bijl].

NIROM Westersche Programma, 15 August 1938, 20:30-21:30.

[Adolphe] Adam. Si j'étais roi (ouverture)

Dvořák. Suite, op. 98

Leoncavallo. Prélude to the $3^{\text {rd }}$ act of Maia

Mascagni. Intermezzo from Cavalleria rusticana

[Ludwig] Grossman[n]. Czardas from Geist des Wojewoden

Gounod. Le tribut de Zamora: Danse espagnole \& Danse italienne

Aside from the 'Toonkunst' concert, the Hawaiian music, and the performance by the Caroline Crooners et al., everything here is what would now be called light classical.' The various distinctions - lunch concert, early afternoon concert, tea-time concert, etc. - do not seem to correlate with differences in programming, though a plain 'concert,' without a timeof-day designation, seems to have been somewhat weightier than the others (See Playlists 1 \& 2).

There are two big omissions in this programming. One is live jazz: there were jazz bands, with Eurasian and sometimes pribumi and peranakan

26 Theo van der Pas (1902-1986) was a prominent Dutch pianist (Encyclopedie van de muziek 1956-57, II:442). He played a Chopin piano concerto in a 1943 radio broadcast under Mengelberg, and his recordings of Beethoven piano sonatas and a Brahms cello sonata (accompanying Emanuel Feuermann) were issued by Columbia.

27 The playing of gramophone records as interludes in live performances occurred not only in Western classical music concerts, but in kroncong and Javanese gamelan programs as well. I have seen no explanations of why broadcasters wanted to do this, so I can only speculate: partly for variety, I imagine; to give the live performers a cigarette break; and perhaps because gramophone technology was still exciting enough (and of improved quality, since the introduction of electrical recording in 1927) that it added glamor to the broadcast. Nevertheless, the juxtapositions could be jarring: in an exchange of letters published in Djawa, Poerbatjaraka and Brandts Buys $(1934: 214,222)$ complain about broadcasts where kroncong records are played in the pauses between Javanese gamelan compositions. 
Chinese ${ }^{28}$ personnel, functioning in Batavia at the time (see Möller 1987), but one didn't hear them on NIROM. ${ }^{29}$ ('Dansmuziek' programs from the Hôtel des Indes and the Societeit Concordia may have included touches of jazz, but one assumes those society orchestras were more sedate than Brown's Sugar Babies or The Musketeers of Swing and other jazz bands Möller names.) And the other is, of course, kroncong, the predominant form of popular music in Indonesia at the time: not a note of live kroncong in the Westersche Programma. ${ }^{30} \mathrm{I}$ have not checked to see whether there were any periods of gramophone music set aside for kroncong, but it seems unlikely. In a survey of everything (including gramophone records) broadcast on all NIROM stations during nine days in May 1938 (this is a separate mini-research project, not presented in this chapter), I found no kroncong at all on the Westersche Programma, neither live nor recorded. Not only was there no kroncong, there was no music with any Indonesian theme not Godowsky's Javanese piano pieces, nothing by Paul Seelig or any of the other 'Indische' composers discussed by Franki Raden (Notosudirdjo 2001) or Henk Mak van Dijk (2007). Virtually the only indication that NIROM's Westersche broadcasting was situated in the Indies is the 'NI' in the station's name.

\section{The Oostersche Programma}

My observations on the Oostersche Programma are based on a detailed tabulation of all of the live music broadcast in 1938 on five ketimuran stations: the two NIROM 'Eastern stations' (that is, the West Java and East/ Central Java sectors of the Oostersche Programma, broadcast from Batavia/Bandung and Surabaya, respectively), as well as VORO (Batavia), VORL (Bandung), and SRV (Surakarta). ${ }^{31}$

28 Persons of mixed Chinese and Indonesian ancestry were termed peranakan. The term could also be used for persons of full Chinese ancestry born in Indonesia, but it implied a degree of assimilation to Indonesian language and culture.

29 Even if NIROM had wished to broadcast Batavian jazz on gramophone records, it could not have mustered more than six minutes, since only one commercial disc of a Batavia jazz band was ever issued. This was His Master's Voice NT 33, released in January 1936, on which The Silver Kings played Dinah and $M a(=M a$, he's making eyes at me). For more on this disc, including a letter from the Sultan of Kutai acknowledging receipt of a copy, see Möller 1987:29, 61.

30 One did, however, hear live broadcasts of both kroncong and Batavia jazz groups on $\mathrm{BRV}$, the private kebaratan radio in Batavia. For a discussion of kroncong in this period, see Yampolsky 2010.

31 Takonai's 2007 article offers a similar study of NIROM's Oostersche programming for two weeks in 1936 (16-31 October) and four weeks in 1942 (4-31 January). His article does not distinguish between live broadcasting and the broadcasting of gramophone records. 
The total absence of Indonesia on NIROM's, Westersche Programma is not mirrored in siaran ketimuran: there is a little bit of Western music on all five stations, and a bit more than a little on VORO, which tried to recognize the heterogeneity of the Batavia population (as did NIROM in the Batavia/Bandung sector of its Oostersche Programma). But the great preponderance of programming on the Eastern stations is eastern, as one would expect given the polarized structure of NIROM's broadcasting. ${ }^{32}$

Many genres are common across the board, though regional preferences or emphases are apparent if we compare the quantities, both of broadcasts and of performing groups:

- Kroncong and Hawaiian were strong on all stations, though Hawaiian was strongest in broadcasts from Solo and kroncong was strongest in broadcasts from Batavia.

- Central Javanese gamelan - one would expect to find it regnant in Solo, but it is surprising to see how prevalent it was in cities not predominantly Central Javanese. It was broadcast regularly both to Batavia and Bandung from the Gedong Museum in Batavia; moreover, the Bupati of Bandung supported a Central Javanese gamelan that broadcast not only performances but also instructional programs. Some of the latter provided accompaniment for dance practice (wireng), but it is not clear how the others instructed. Perhaps aspiring musicians played at home on their gender or rebab along with the radio broadcast?

- Macapat, a Central Javanese genre of sung poetry using a variety of stanza patterns with associated vocal melodies, was also well represented (both as performance and as instruction) not only in Solo but also on the Surabaya station, and, to a lesser extent, as performance only, in Batavia. It was, however, wholly absent from Bandung.

- Sundanese music, strong in Bandung (of course) and Batavia, was nonexistent on SRV and negligible on NIROM Surabaya.

- East Javanese genres had no presence anywhere but in Surabaya.

- Chinese music was relatively well distributed, though weak in Solo and weaker still in Bandung.

32 I will return to the matter of polarization later in this chapter. For now, it is sufficient to note the existence of a Western Programme broadcast entirely in Dutch, with a program guide published in Dutch and all of its music wholly Western; and an Eastern Programme broadcast entirely in Indonesian, with its program guide in Indonesian and its programming devoted to music of Asia with only a slight touch of the West. 
- Gambus and harmonium orchestras, which had explicit Muslim associations, were most energetically broadcast in Batavia and Surabaya.

- Sumatran music was largely a concern of NIROM, though VORO also addressed the Minangkabau population in Batavia. ${ }^{33}$

What is not here? There is surprisingly little Muslim devotional music, though there were certainly lectures on Islam and there was live Qur'anic recitation (pengajian). ${ }^{34}$ Again no jazz; I don't understand why not though the eclectic Hawaiian programs (see below) included some songs that could be counted as jazz or what was called hot music (in Indonesia as in Europe and the U.S.). There is also nothing from Kalimantan, or Sulawesi, or anywhere east of Bali, and hardly anything from Bali itself. Given the prominence of Balinese gamelan in today's picture of Indonesian music, we may find this puzzling, but we must remember the constraints of radio in those years. Since there was no studio in Bali, the only way Balinese gamelan could be broadcast live would be for a gamelan to be transported to one of the Javanese cities with a studio - an expensive proposition. ${ }^{35}$ (The lone form of Balinese music broadcast on these stations in 1938 is janger, broadcast three times by SRV; but janger, requiring only singers and a few instruments, was far more portable than a full

33 VORO broadcast programs of 'lagoe-lagoe Minangkabau aseli' (old-style Minangkabau music; this translation of asli is discussed in footnote 82 below), performed by the Perkoempoelan A.S.A. under the direction of Tamimi gelar Soetan Roemah Tinggi, 22 times in 1938 - not at all in the first three months, but four times in April, five times in May, and two or three times each month thereafter. Although outnumbered by Melayu in Batavia, the Minang were the only Sumatran ethnic group VORO programmed for. The reason for singling them out may be simply what the director of VORO explained in a disgruntled-sounding article in January 1937 after NIROM reduced its subsidy to the station: 'Before [i.e. when VORO was tailoring its programming to NIROM's requirements], VORO had to pay attention to all the groups of people of the East [semoea golongan dari bangsa Timoer] and had to play music from all of them. Now we are working only for our own members. So if, for example, we have no one with a Hindu name in our membership list, we don't have to play Hindu music. Hindus can look for their music on NIROM. They are obliged to pay NIROM every month, so it is their right to hear the music they care for. If they become members of VORO, then VORO will be obliged to play the music they like' (Pewarta V.O.R.O. 1937a). So VORO must have had members with Minang names, but none with Batak or Melayu names. Probably there were more Minang than other Sumatrans in Batavia who were interested in radio and also able to pay for both NIROM (obligatory) and VORO (optional).

${ }^{34}$ I have excluded pengajian from the tabulation because in Islam recitation of the Qur'an is not considered music.

35 But not, apparently, impossible: on 5 March 1941 Mangkunegara VII sponsored a malam kesenian Bali (Balinese arts night) that was broadcast live over SRV (Wiryawan 2011:93). Perhaps a Balinese troupe was on tour. 
Balinese gamelan.) The same applies to Kalimantan and the 'Great East': unless there were performers and instruments in the cities on Java that had radio studios, there could be no live broadcasts of their music. ${ }^{36}$

\section{Specific Genres}

The program guides reveal interesting aspects of the character of various genres in radio performance. One is the elasticity of some of them. For example, broadcasts of East Javanese gamelan music from the NIROM studio in Surabaya were often interspersed (diselingi) with pieces played by the studio's angklung orchestra. ${ }^{37}$ Gambus broadcasts typically consisted of seven or eight numbers, of which most were sung in Arabic but at least two were 'extra Melajoe' (Playlists 3 and 4).

This idea of the extra needs investigation. The term appears frequently in the playlists for radio broadcasts, where it usually seems to mean any piece of music outside the normal style or repertoire of the principal genre being broadcast. The term is close to selingan (alternation, insertion), as with the angklung in the broadcasts of East Javanese gamelan music, but it is more flexible: if genre $\mathrm{A}$ is diselingi with genre $\mathrm{B}$, you can expect to hear those two kinds of music, genres A and B. ${ }^{38}$ But if genre

36 Nor were there any gramophone records of music from Kalimantan or the eastern islands at that time. There were, however, recordings of Balinese music, and these were played on the radio.

37 This orchestra is something of a mystery. Angklung is a Javanese and Balinese folk instrument, most common in West Java, consisting of two or more bamboo tubes tuned in octaves and loosely mounted in a frame; when the frame is shaken the tubes strike the frame and emit their pitch. Traditionally, angklung in Java are played in tuned sets producing only a few pitches or at most a pentatonic scale, but in 1938 a schoolteacher in West Java named Daeng Soetigna began making angklung sets tuned to Western scales and capable of playing European melodies. (The pinpointing to 1938 comes from Sumarsono and Pirous 2007:xxi.) What then was the angklung orchestra of NIROM's Surabaya studio playing in 1938? Javanese folk music with traditionally tuned angklung? That music has a very limited repertoire. Was it an East Javanese version of Daeng Soetigna's diatonic angklung? This would be the first indication I have seen that Soetigna's innovation spread so rapidly out of West Java (or alternatively that it emerged independently in East Java). Was it a Surabaya version of the Banyuwangi ensemble known as angklung but featuring bamboo tube-xylophones rather than shaken tube-rattles? It seems extremely unlikely that it could have been any form of the Balinese gamelan angklung.

38 The combinations could be pretty strange. Witness the fifth anniversary concert of The Jolly Gipsies, a children's Hawaiian group in Solo. In this performance, broadcast over SRV on 19 November 1938, Hawaiian songs, the focus of the program, were interspersed with Javanese gamelan music (diseling dengan klenengan). Or the performance (klenengan) of Central Javanese gamelan music by the group Mardiwiromo broadcast by VORO on 1 January 1936, which had interpolations of kroncong and Melayu songs played (live) by Krontjong Orkest Zevental. 
A is your main program, and there are 'extra songs' (lagu extra), you don't know what genre or genres they might belong to. The term apparently derives from the practice of the bangsawan or stambul theater, where 'extra' songs and dances, unrelated to the plot - cakewalks, cariocas, dances from India, whatever - could be inserted as entr'actes.

On the other hand, in the repertoire of Sundanese tembang (the highstatus genre that was the normal repertoire of the many groups called ketjapi orkest), the lagu extra (later called panambih) became not a whatever but a specific type of song. In a typical performance of tembang Sunda, a group of unmetered tembang, all using one tuning or scale, would be followed by a metered panambih in the same tuning or scale. ${ }^{39}$

PLAYLIST 3: GAMBUS

Gamboes Orkest "Rozen" dipimpin oleh toean Rozen Bahar, dinjanjikan oleh toean A. Salmin. [Gambus Orkest "Rozen," directed by tuan Rozen Bahar, with tuan A. Salmin, singer].

NIROM Oostersche Programma (Batavia/Bandoeng), 8 May 1938, 23:00-24:00.

Lagoe Pemboeka'an

Rumba Carioca

Achi Ittifaag

Golbie Tamanna

Boewah Tandjoeng (selingan)

Ali Baba Rumba

Lagoe Penoetoep

\section{PLAYLIST 4: GAMBUS}

Gamboes Orkest "Alhambra" dari Batoe dipimpin oleh toean S. Oemar Hamoed Talib, di dalam Studio Nirom, memperdengarkan matjam2 lagoe Arab. [The Gambus Orkest "Alhambra" from Batu, directed by tuan S. Oemar Hamoed Talib, in the NIROM studio, presents a variety of Arabic songs.] NIROM Oostersche Programma (Soerabaia), 5 January 1938, 20:30-23:00

Iftitah Marsch

Sjarah Arabië "Haman"

Extra Melajoe

Billas Jahabibie

39 As I say, the term panambih (Sundanese: additional, or a supplement) only came into use later, but to distinguish the specifically Sundanese lagu extra from other lessdefined kinds of lagu extra, I will use the term panambih before its time. 
Idhadhaga

Mama

Sjarah Arabië "Holkin”

Extra Melajoe Idjo Idjo

Usually sung by women (whereas the unmetered tembang could be sung by men or women), their lyrics concerned love and natural beauty, and the songs carried a subtle erotic charge. Partly because of the star female singers and partly because fixed meter made the songs more accessible, lagu panambih were more appealing to the general public than the old-fashioned, unmetered tembang, and the gramophone industry favored them for this reason, recording far more panambih than tembang.

On radio, however, panambih often appear paired with a tembang from the standard repertoire (Playlist 5), or yet more classically, as a pendant to a group of tembang (Playlists 6 and 7). That is to say, they are kept within the classical frame and are not allowed to become free-standing, as they often were on records. I interpret this as showing that the support for tembang Sunda on radio was mainly conservative, interested in maintaining the genre's prestigious, aristocratic associations, while the gramophone industry simply sought what sold. (It reminds us that radio and gramophone were, as I remarked earlier, different media, with different considerations.)

PLAYLIST 5: TEMBANG SUNDA

Ketjapi Orkest "Balebat" dipimpin oleh toean Djoehrie, soeara Nji Mas Djoedjoe. [Kacapi Orkest "Balebat," directed by tuan Djoehrie, with Nji Mas Djoedjoe, vocal.]

NIROM Oostersche Programma (Batavia/Bandoeng), 7 August 1938, 19:00-21:00

Bajoeboed extra Renggong Gede

Sinom Panangis extra Boengoer

Kentar Adjoen extra Senggot Pelog

Sinom Tjirebonan extra Tjatrik

Oedanmas Karatonan extra Bandjaran Miring

Eros extra Rara-rara kring Panglima

Sinom Satria extra Senggot Ys Lilin

Boebaran 
PLAYLIST 6: TEMBANg SundA

Ketjapi Orkest "Sekar Familie" dengan penjanji tembang jang terkenal dari Tjiandjoer Enden Imong, dipimpin oleh toean R. Emoeng Poerawinata. [Kacapi Orkest "Sekar Familie," with the famous tembang singer Enden Imong from Cianjur, directed by tuan R. Emoeng Poerawinata.]

NIROM Oostersche Programma (Batavia/Bandoeng), 5 July 1938, 20:30-23:30

Tembang dalam soeroepan Pelog:

Pemboeka'an lagoe Papalajon

Dandanggoela Bajoeboed

Dandanggoela Kentar

Dandanggoela Mangari

Sinom Liwoeng

Sinom Panangis

Sinom Tjirebonan

Extra Renggong Gantjang

Liwoeng Djaja

Djemplang Serang

Tembang dalam soeroepan Sorog:

Sinom Pangrawit

Sinom Satrija

Sinom Kapati-pati

Extra Boengoer

Asmarandana Embat-embat

Asmarandana Karaton

Kinanti Oedanmas

Extra Bandjaran

Papantoenan dalam soeroepan Pelog:

Papatet

Moepoekembang

Radjamantri

Randegan

Sampioeng

Djemplang Penganten

Djemplang Titi

Extra Tjatrik

\section{PLAYLIST 7: TEMBANG SUNDA}

Ketjapi Orkest "Rekamaja," dipimpin oleh toean Moehamad Bakri, soeara Nji Moemoen. [Kacapi Orkest "Rekamaya," directed by tuan Moehamad Bakri, with Nji Moemoen, vocal.] 
NIROM (Batavia/Bandoeng), 2 September 1938, 19:00-19:45, 20:00-20:30.

Soeroepan Pelog: Papantoenan

Papatet

Randegan

Sampioeng

Djemplang Penganten

Extra Senggot Pelog

Soeroepan Sorog

Sinom Pangrawit

Sinom Satrija

Sinom Kepati-pati

Kinanti Oedanmas

Extra Bandjaran

Turning to the two ubiquitous genres of popular music, kroncong and Hawaiian, we find - as further examples of the elasticity of genres on radio - that both had by 1938 expanded quite a bit beyond their core repertoires.

KRONCONG. Playlist 8 shows a broadcast by the Krontjong Orkest Lief Souvenir, from Batavia. It mixes kroncong and stambul tunes ${ }^{40}$ with songs in the general Batavia repertoire (Djali-djali, Persi roesak, Kramat Karem) available to any popular musicians in Batavia. (The Chinese-Betawi gambang kromong ensemble, for example, played all three of these tunes.) Note that although this is nominally a kroncong broadcast (since the performing group is called a krontjong orkest) only four of the ten named tunes (ignoring the opening and closing signature tunes) are kroncong. One other is a stambul, and all the rest are lagu extra, three of which have, like kroncong itself, associations with Batavia. Thus, though the songs themselves are diverse in form and idiom, a Batavian theme pervades the broadcast.

The Melody Band in Surabaya (Playlist 9) offers another heterogeneous program, this one without a localizing theme. Though the group is billed as a krontjong-orkest and the broadcast is listed in Soeara Nirom as a program of 'original [i.e., in this context, old-style] and modern kroncong and stambul songs,' there are no stambul and only two explicit kroncong numbers (though some of the other songs may be kroncong without saying so in their titles), along with seven songs in English, a nostalgic number

\footnotetext{
40 In the context of the 1930s, stambul songs can be considered a distinctive subrepertoire of kroncong.
} 
harking back to the legendary Portuguese origins of kroncong (Nina boeboek), a song associated with the peranakan Chinese (Poekoel gambang; Miss Tioe, the Melody Band's star female singer, was peranakan), three songs associated with the Melayu and Minang of Sumatra (Sirih koening, Tjik Mamat, Simambang Boekit Tinggie), and one (Sontolojo) with a probable East Javanese connection. ${ }^{41}$ Koesbini, a versatile singer and composer, apparently specialized in songs in languages other than Indonesian, so the prominence of English-language songs here is probably meant to showcase this talent. Other kroncong broadcasts by The Melody Band included Koesbini singing in German and Dutch, as well as songs (with other singers) associated with Ambon, Manado, and Bengkulu.

\section{PLAYLIST 8: KRONCONG}

Krontjong Orkest "Lief Souvenir" dipimpin oleh Soewardi dibantoe oleh violist Abdul Karim dan penjanji2 Miss X, Deetje, serta Djajasoepena. [Kroncong Orkest "Lief Souvenir," directed by Suwardi, with Abdul Karim, violin, and the singers Miss X, Deetje, and Djajasoepena.]

NIROM Oostersche Programma (Batavia/Bandoeng), 12 May 1938, 20:35-22:00

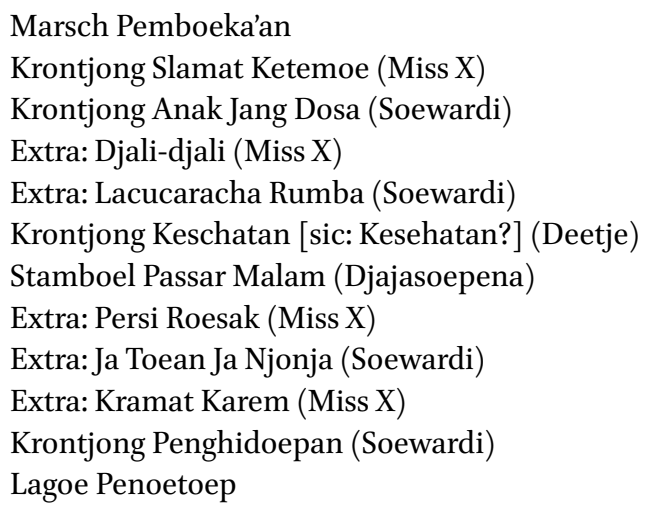

Playlist 10 shows a third kroncong broadcast, this one by the famous Batavia group Lief Java, here with a guest singer, Miss Roekiah, a recording star

41 An East Javanese gamelan composition with this title was included three times in 1938 in broadcasts of East Javanese gamelan music by NIROM's Surabaya studio gamelan (klenengan dari Studio Nirom meloeloe gending2 Djawa Timoer). The song performed by The Melody Band could be musically related to this East Javanese melody (or to the Central Javanese Ladrang Sontoloyo, reported to me by Marc Perlman), or it could simply have borrowed the title. Note that in another broadcast by The Melody Band, Koesbini sang Krontjong Gembala Sontolojo, which is probably the same song as in Playlist 9, under a different title. 
particularly prominent in 1938 because of her leading role in the first Indonesian-language hit movie, Terang boelan, whose title song she sings in the broadcast. We find Betawi songs, Sumatran songs (Kota Silindoeng tjantik, Danau Toba, Sri Landak), a Chinese reference (Peking diwaktoe malam), a Javanese reference (Poelau Djawa), and the bare minimum of stambul and kroncong (one each). No songs in English, this band having a film star but no Koesbini. What is being conveyed here? Lief Souvenir, calling itself a krontjong orkest, treats kroncong as an element of Batavian music, not as a self-limiting genre. The other two groups, while still claiming to be kroncong ensembles or to offer programs of kroncong and stambul, also travel far outside the formal constraints of those genres, and at the same time they strive to expand their nominal kroncong into a pan-Indonesian popular music not by presenting actual melodies in local performance styles from across the country, but by adapting and arranging melodies in the string-band idiom (inevitably using Western tunings and harmonies), or, when that is unfeasible because the melodies resist adaptation, by avoiding musical references and instead simply mentioning regions and ethnicities in the lyrics of the songs. Koesbini's Melody Band makes a further effort to connect this expanded kroncong to international popular music.

PLAYLIST 9: KRONCONG

Krontjong-Orkest "The Melody Band" dipimpin oleh toean-toean Koesbini dan Moechtar di dalam Studio Nirom, memperdengarkan matjam 2 lagoe krontjong dan stamboel jang origineel dan modern. [Kroncong-Orkest "The Melody Band," directed by tuan Koesbini and tuan Moechtar in the NIROM studio, presents a variety of kroncong and stambul songs, both old-style and modern.] [Note: the singers are Koesbini and Miss Tioe.]

NIROM Oostersche Programma (Soerabaia), 9 January 1938, 20:30-23:00

Lagoe Pemboeka'an

Serenade (Miss Tioe)

Nanking Rumba (Koesbini)

Kiss Me Goodnight (Koesbini)

Goodnight Marie (Koesbini)

Krontjong Prempoean Sedjati (Miss Tioe)

Krontjong Oh, Manoesia (Koesbini)

Poekoel Gambang Poekoel Piano (Miss Tioe)

Nina Boeboek (Koesbini)

Sinar Mataharie (Miss Tioe)

Sorga Doenia (Koesbini) 


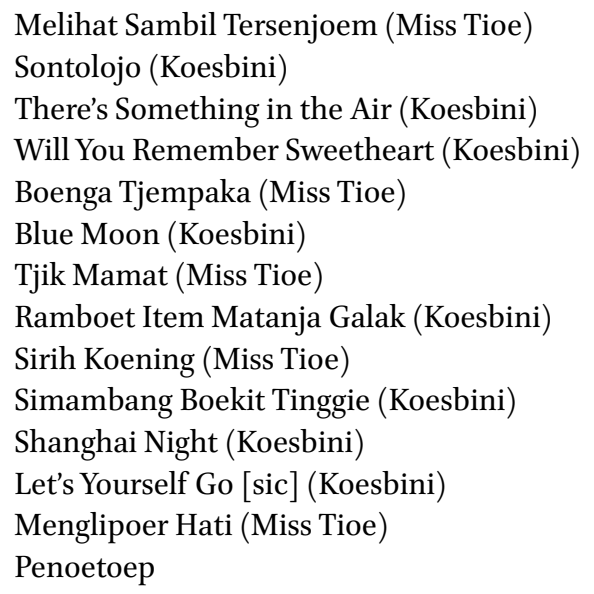

\section{PLAYLIST 10: KRONCONG}

"Terang Boelan" - speciaal krontjong programma dimainkan oleh "Lief Java" dipimpin oleh Hugo Dumas dan dibantoe oleh Miss Rukyah [=Roekiah] dan lain-lain penjanji jang terkenal. [Terang Bulan - a special kroncong program played by "Lief Java," directed by Hugo Dumas, with Miss Rukyah and other well-known singers.]

NIROM Oostersche Programma (Batavia/Bandoeng), 13 June 1938, 21:30-24:00

Marsh [sic] Pemboeka'an

Terang Boelan (Miss Rukyah) [=Roekiah]

Poelau Djawa (Ismail dan Koor)

Bungah Mawar (Miss Rukyah)

Peking Diwaktoe Malam (Louis Koch)

Djali-djali (Jan Boen)

Bergirang Hati (Miss Rukyah)

Duduk Termenung Ditepi Laut (Miss Rukyah)

La Cumparsita (Instrumental)

Kota Silindoeng Tjantik (Zahirdan)

Persi Roesak (Miss Rukyah)

Fatimah! Gadys Desa (Miss Rukyah)

Stamboel "Poespa Warna" (Louis Koch)

Danau Toba (Ismail)

Waktu Makan (Miss Rukyah)

Menyesal (Miss Rukyah)

Krontjong Boenga Melati (Louis Koch)

Sri Landak (Extra Malay Turn) (Koor)

Gelombang Laut (Miss Rukyah)

Selamat Malam 
PLAYLIST 11: HAWAIIAN

Siaran dari Studio Nirom di Soerabaia, memperdengarkan lagoe2 Hawaiian dimainkan oleh The Twilight Minstrels. [A broadcast from the NIROM studio in Surabaya, presenting Hawaiian songs played by The Twilight Minstrels.]

NIROM Oostersche Programma (Soerabaia), 13 January 1938, 21:00-23:00

There's a Star in the Sky

Time on My Hands

Violeta

Underneath the Palms

Where Are You

Pretty Red Hibiscus

Over Somebody Else Shoulder [sic]

Dinah

Let's Start Our Love Anew

I Wish I Were Twins

Just Say "Aloha"

Basin Sheet Blues [sic!]

Apple Blossom Time

So Nice

I'd Rather Be a Beggar with You

\section{PLAYLIST 12: HAWAIIAN}

Hawaiian Orkest "The Twilight Minstrels" dipimpin oleh toean Tan Hong Djwan di dalam Studio Nirom, memperdengarkan matjam lagoe Hawaiian. [Hawaiian Orkest "The Twilight Minstrels," directed by tuan Tan Hong Djwan in the NIROM studio, presents a variety of Hawaiian songs.]

NIROM Oostersche Programma (Soerabaia), 4 August 1938, 21:00-23:00

I'd Like to See Samoa of Samoa

Honolulu Hula Hula Heigh

O Mine Ha Ha [=Minnehaha?]

Harbor Light

Love and Learn

Little Heaven of the Seventh Seas [sic]

Toodle-oo

Moon or Moon [sic]

Sentimental Gentlemen from Georgia

China Sea

Is It True What they Say about Dixie

A Night by the Ocean 
HAWAIIAN. Again we have an expanded genre: while Hawaiian broadcasts always contain songs with Hawaiian or South Seas reference (I'd like to see Samoa of Samoa, Just say aloha), they also include popular and light jazz tunes. But never does a Hawaiian program include a kroncong, or indeed any song in Indonesian; and neither do kroncong programs include Hawaiian songs. This is quite striking, considering the near-identity of the instrumentation for kroncong and Hawaiian. One might think the distinction between the genres was racial, but both kroncong and Hawaiian ensembles included the same mix of Eurasian, peranakan Chinese, and pribumi performers. The most plausible explanation is that the genres were kept distinct in language and repertoire because of the audiences they were expected to reach: Hawaiian, sung in English (or Hawaiian), was aimed at an audience oriented to the wider world outside Indonesia, while kroncong focused either narrowly on Batavia (e.g. Playlist 8) or more broadly on Indonesia (Playlists 9 and 10). Koesbini evidently tried to widen kroncong's focus to include European/American popular music as well (as in Playlist 9), but such songs were folded into a predominantly Indonesian context, whereas Hawaiian broadcasts simply eliminated Indonesia from the discourse. ${ }^{42}$

\section{In the Air}

A public medium necessarily takes a stance on public issues, if only by remaining silent about them. In this second section I consider what radio

42 By 1940 this had changed, and some groups performed Hawaiian songs with lyrics in Indonesian. The earliest instance I have seen so far of this subgenre, called langgam Hawaii or langgam Hawaiian, is a NIROM broadcast on 9 February 1940. A comment, interesting both for its essentialism and for its view of what popular music can do, is found in Soeara-Nirom 1940g: 'Hawaiian songs and Hawaiian guitar are very popular these days not only the lovely instrumental music but also the songs in English and Hawaiian. Hawaiian music opens a road for our young people to advance by way of music and singing. Not only young men, but also our young women now have the courage to come forward without fear or shame. Because they are Eastern, Hawaiian songs are very accessible, and they are also easily made suitable to conditions in our country. Now the songs called langgam Hawaii have emerged, which are Hawaiian songs and music but with singing in our language here' (emphasis added).

The Indonesian text: 'Lagoe dan guitaar Hawaii sekarang sangat popoeler sekali djadinja, sehingga boekan sadja digemari orang moesiknja jang indah itoe, melainkan djoega boeah lagoenja didalam bahasa Inggeris dan Hawaii. Teroetama lagoe Hawaii itoe memboekakan djalan kepada pemoeda kita oentoek mentjari kemadjoean didalam moesik dan bernjanji, boekan sadja bagian pemoeda, poen pemoedi kita soedah berani tampil kemoeka dengan tidak oesah gentar dan maloe lagi. Karena lagoe Timoer, maka lagoe Hawaii itoe moedah benar diterima, dan moedah poela disesoeaikan kepada keadaan dinegeri kita ini. Demikianlah lahir lagoe langgam Hawaii itoe, jaitoe lagoe dan moesiknja menoeroet langgam Hawaii sedang boeah njanjinja bahasa kita disini.' 
and radio music had to say or show about two of the central issues of the DEI in the late 1930s: the unity or disunity - racial, ethnic, and political of colonial society; and the nature and impact of modernity. ${ }^{43}$

\section{East vs. West}

In March 1939, the prominent Indonesian nationalist Hadji Agoes Salim published a two-part essay titled Radio dan masjarakat (Radio and society) in the Medan newspaper Sinar Deli. ${ }^{44}$ In the first part of the essay, Pertjeraian Bangsa (Separation of peoples), Salim criticizes NIROM for failing to implement radio's potential to bridge the gap between Indonesians and the Dutch. He writes:

In virtually every government office and every business, various peoples meet and mix, especially Dutch and Indonesians. This is also the case in nearly every school. But outside of official business, association [pergaoelan] between Easterners and Westerners, especially Dutch and Indonesians, rarely - in fact, one may say, never - takes place. The two peoples deliberately distance themselves from each other. The Dutch do not want to mix freely with the Indonesians, seeming to feel that they will be lowered by the association; and the Indonesians avoid contact with the Dutch in order to protect themselves from opinions and behavior they feel are insulting. Although more and more Indonesians have 'Western' education and hold 'Western' rank and position, this has not decreased the separation, which has instead grown more rigid, perhaps fueled by competition. ${ }^{45}$

43 This second half of the present chapter is no longer restricted to 1938.

44 Salim 1939. Part 1, 'Pertjeraian bangsa,' was published in Sinar Deli on 23 March 1939, and Part 2, 'Pertjeraian golongan,' on 28 March 1939. 'Pertjeraian bangsa' was later republished in the Surakarta newspaper Darmo-Kondo over two days (11-12 April 1939), but I could not find 'Pertjeraian golongan' in that paper.

45 'Dalam tiap2 pedjabatan dan tiap2 peroesahaan pemerintah atau pertikoelir hampir rata2 bertemoe tjampoeran berbagai bagai bangsa, teroetama bangsa Belanda dan bangsa Indonesia. [Paragraph] Demikian djoega hampir dalam tiap2 sekolah. [Paragraph] Tapi soenggoehpoen begitoe pergaoelan antara bangsa Timoer dan Barat teroetama antara bangsa Belanda dan bangsa Indonesia, diloear oeroesan djabatan (officieel) hampir, malah boleh dikatakan sekali kali, tidak ada. Dengan sengadja doea pihak itoe mengasingkan diri antara satoe dgn lain. Bangsa Belanda tidak maoe ketjampoeran 'anak negeri', dalam pergaoelan merdeka, seolah olah koeatir akan mendjadikan rendah pergaoelannja djika ketjampoeran. Maka dgn sendirinja bangsa Indonesia mengasingkan diri soepaja terpelihara dari pada anggapan dan perlakoean jg dirasakannja sebagi perhinaan. Dengan bertambah banjaknja bangsa Indonesia jg berpeladjaran 'Barat' dan mendoedoeki pangkat dan djabatan 'Barat', boekanlah bertambah koerang pisahan itoe, malah bertambah keras. Seolah olah ditambah keras oleh nafsoe persaingan!' (Salim 1939). The abbreviations $d g n$ and $j g$ are in the published text. 
Such apartness, Salim says, is dangerous and runs counter to the ideals of human well-being and progress (hadjat kemanoesiaan dan kemadjoean). Thus it distresses him to see that while NIROM's Oostersche Programma broadcasts the songs of Indonesians, Chinese, Indians, Malays, Arabs, and also (like the Westersche Programma) songs in English, Hawaiian, and Maori,

evidently the Dutch language is forbidden [pantangan] for Eastern broadcasting, and songs in Indonesian are forbidden for Western broadcasting. And the music and Western songs called classical seem also to be forbidden for NIROM's Eastern broadcasting. ... With this policy, NIROM, a halfway official body, becomes as it were propaganda for and a demonstration of the separation of peoples, with the approval of the ruling power. ${ }^{46}$

Salim praises VORO, the private ketimuran station in Batavia, for broadcasting some Dutch-language programs. This is appropriate, he says, given that thousands of Indonesians understand and indeed speak Dutch (particularly, he could have added, in the kinds of families that could afford radios).

This is a curiously one-sided attack. In the first place, it is not quite fair: the Oostersche Programma did (as Salim acknowledges) broadcast its Padvinders (scouting) program in Dutch (spoken by an Indonesian broadcaster); it also, to celebrate the birthdays of the royal family or the anniversary of the Queen's succession to the throne, broadcast programs with Dutch-language songs 'especially for those of the Orange group, ${ }^{47}$ and from time to time kroncong with Dutch titles were included on kroncong playlists even when there was no special occasion. ${ }^{48}$ (But aside from these few contexts, Salim is right that the Dutch are barely present in the Oostersche Programma.)

46 'Hanja roepanja basa Belanda mendjadi pantangan oentoek siaran Timoer, sebagai djoega lagoe2 dan njanjian basa Indonesia mendjadi pantangan oentoek siaran Baratnja. Begitoe poela lagoe2 moesik dan njanjian Barat jg dinamakan klassiek seolah2 mendjadi pantangan poela oentoek siaran Timoer Nirom. ... Dengan lakoe jg demikian itoe, Nirom jg bersifat setengah djabatan seolah2 mendjadi propaganda dan demonstratie pisahan bangsa dgn kebenaran dari pihak kekoeasaan' (Salim 1939).

47 In 1938, these songs included the anthems Wilhelmus and Wien Neerlandsch bloed, and various popular tunes: Zandvoort, Draaien draaien, Ik hou van Holland, Zilver tusschen 't goud, Je hebt een hart van goud, Van je heidel doedel dee, Hei hei meisjelief, Omdat ik zooveel van je hou, and Het meisje van de overhaal.

48 I am not certain that the lyrics of these songs were in Dutch, though the titles were. Some of these titles from 1938 broadcasts are: Krontjong Tanah Abang bij nacht, Krontjong Nirom bij nacht, Krontjong Java bij nacht, Krontjong Parijs van Java, Krontjong Melati van Java, Krontjong Het Zevental, Krontjong De Bliksem, Krontjong De Regenboog, etc. 
Secondly, why does he lash out at the Oostersche Programma like this yet skim lightly over the Westersche Programma? Judging from my Westersche surveys for 1938, nothing from Indonesia, words or music, was broadcast on the Western Programme. NIROM operated on the premise that Dutch listeners wanted nothing but European music, and Asian listeners wanted nothing but Asian music. ${ }^{49}$

But was this premise true? Pertjeraian golongan ('Separation of groups'), the second part of Hadji Agoes Salim's 1939 essay, concerns social rather than racial divisions in the DEI. The only people who have radios, he writes, are those who can afford to buy the machines and pay for the license and the electricity - 'a very thin stratum of society.' Even high government officials (ambtenar2 sampai pangkat kontrolir jg mengepalai pemerintahan negeri) say they cannot afford radios, so certainly the mass of ordinary people (whom he calls rakjat ramai and lapisan tengah dan lapisan sibanjak daripada rakjat anak negeri) cannot. This is surely correct; but if only the wealthy could afford radios, is it likely that those Asians among them (some 40,000 in 1938, according to Table 2.2), many with enough wealth and privilege to afford Western education and Western interests, listened only to Asian music? Or consider the 45,00o Europeans who held radio licenses at the end of 1939: Witte (1998:125) points out that 28,000 of them were actually Eurasians with European status, ${ }^{50}$ and, as I remarked earlier, Eurasians had one foot in each camp. Undoubtedly many of them were listening to both Western and Eastern music. ${ }^{51}$

Anyone could turn the dial from west to east and back again. Indeed, while De N.I.R.O.M.-Bode contained detailed schedules of two weeks of Westersche broadcasting, and Soeara Nirom contained equally detailed listings for Oostersche broadcasting, each also provided a one-page

49 Recall the justification NIROM offered for establishing its separate Oostersche Programma, quoted earlier (see footnote 18): 'Eastern music is not much liked by the European public, just as the Indonesian public does not much like European music.' 'Not much liked' sounds to me like a faint-hearted way of saying 'rejected.'

50 For the reason discussed in footnote 24, Witte presents this figure in incorrect reference to 1940 rather than 1939.

51 In August 1967, the Djakarta Times published an article describing kroncong as 'typically Indonesian.' The article was later translated into Dutch and published in Tong Tong, a magazine aimed at 'Indos' (Eurasians) living in Holland. See 'Krontjong: een manifestatie van typische Indonesische muziek', Tong Tong 12-16 (29 February):5,1968. The translation was accompanied by an anonymous editorial comment (probably by Tjalie Robinson) remarking (disapprovingly) on the furious reaction of some Eurasians that 'kroncong is NOT Indonesian, it comes from us!' (Krontjong is NIET Indonesisch, maar 'van ons.') Recall that kroncong did not appear at all in NIROM's Westersche Programma - but clearly it had listeners who were classified as Europeans. 
summary of the other programme's schedule for those two weeks. An invitation, perhaps. And a listener who wanted to pay the money could subscribe to either program guide, or both. ${ }^{52}$

One further instance of modest - but not nonexistent - crossover. In April 1936, De Nirom-Bode published the results of a poll taken earlier that year (De Nirom-Bode 1936). NIROM had held an election for a board of advisers, and it asked all who voted in that election, 5884 listeners, which programme they preferred to listen to, the Westersche or the Oostersche. Then, on the basis of the listeners' names, NIROM sorted the responses into three categories: Europeans, Natives, and Chinese. The results are shown in Table 2.3.

Table 2.3. Results of 1936 NIROM questionnaire regarding listener preferences for Westersche or Oostersche Programma.

\begin{tabular}{|c|c|c|c|c|c|}
\hline & & Europeans & $\begin{array}{l}\text { Pribumi } \\
\text { ('Natives') }\end{array}$ & $\begin{array}{l}\text { Chinese } \\
\text { \& Other } \\
\text { Asiatics }\end{array}$ & Total \\
\hline 1 & $\begin{array}{l}\text { \# of respondents to } \\
\text { NIROM } \\
\text { questionnaire }\end{array}$ & $?$ & $?$ & $?$ & 5,884 \\
\hline 2 & $\begin{array}{l}\% \text { of NIROM } \\
\text { respondents (line } \\
\text { 1) preferring } \\
\text { Westersche } \\
\text { Programma }\end{array}$ & $98.1 \%$ & $6.6 \%$ & $30.5 \%$ & \\
\hline 3 & $\begin{array}{l}\text { \% of NIROM } \\
\text { respondents (line } \\
\text { 1) preferring } \\
\text { Oostersche } \\
\text { Programma }\end{array}$ & $1.9 \%$ & $93.4 \%$ & $69.5 \%$ & \\
\hline 4 & $\begin{array}{l}\text { \# of radio license } \\
\text { holders - end } 1935\end{array}$ & 19,020 & 4,411 & 4,135 & 27,566 \\
\hline 5 & $\begin{array}{l}\% \text { of total \# of } \\
\text { license holders } \\
\text { (line } 4)\end{array}$ & $69 \%$ & $16 \%$ & $15 \%$ & $100 \%$ \\
\hline
\end{tabular}

(Continued)

52 The guides did not come free with the license fee. In 1937, a subscription to Soeara Nirom cost an additional fo.25 a month. 
Table 2.3. (Cont.)

\begin{tabular}{|c|c|c|c|c|c|}
\hline & & Europeans & $\begin{array}{l}\text { Pribumi } \\
\text { ('Natives') }\end{array}$ & $\begin{array}{l}\text { Chinese } \\
\text { \& Other } \\
\text { Asiatics }\end{array}$ & Total \\
\hline 6 & $\begin{array}{l}\text { Putative \# of all } \\
\text { license holders } \\
\text { preferring } \\
\text { Westersche } \\
\text { Programma } \\
\text { (applying \% in line } \\
2 \text { to \# in line 4) }\end{array}$ & 18,659 & 291 & 1,261 & $\begin{array}{l}20,211 \\
(73 \cdot 3 \% \\
\text { of line } 4 \\
\text { total })\end{array}$ \\
\hline 7 & $\begin{array}{l}\text { Putative \# of all } \\
\text { license holders } \\
\text { preferring } \\
\text { Oostersche } \\
\text { Programma } \\
\text { (applying \% in line } \\
3 \text { to \# in line 4) }\end{array}$ & 361 & 4,120 & 2,874 & $\begin{array}{l}7,355 \\
(26.7 \% \\
\text { of line } 4 \\
\text { total })\end{array}$ \\
\hline
\end{tabular}

Sources: Lines 1 \& 2: De Nirom-Bode 1936; line 4: Indisch verslag, part 2, for 1938 (published 1939). Other lines extrapolated from Lines 1, 2, \& 4.

It is probably no surprise that some $98 \%$ of the Europeans preferred the Western programme, and not much of one that $93 \%$ of the Indonesians preferred the Eastern programme - though the $2 \%$ of Europeans and $7 \%$ of Indonesians listening against type are of interest. The surprise is among the Chinese, $30 \%$ of whom chose the Western programme and $70 \%$ the Eastern.

So there is considerable likelihood, and some evidence, of listening across racial boundaries. In the discourse of Indies radio, however, everyone stays in his or her box. We have seen this already in the east/west opposition that justified the creation of the Oostersche Programma; but it was strong also in ketimuran rhetoric. For example:

The broadcasting of Eastern music now is far from satisfactory. Radio listeners are stuffed full of Western music, which is obviously not enjoyed by Chinese, Arabs, or Indonesians. ${ }^{53}$

53 'Sekarang sadja penjiaran lagoe-lagoe Timoer soeda djaoeh dari memoeasken. Pendenger-pendenger radio terlaloe banjak didjedjel dengen lagoe-lagoe Barat, jang tentoe sekali ada tida menjotjokin bangsa Tionghoa, Arab atawa Indonesiers' (Pewarta Soerabaia 1938b). 
Similarly, most of the rationales offered for the formation of the Federation of Eastern Broadcasters (PPRK) are essentialized expressions of the box mentality: 54

Eastern broadcasting should be managed by Eastern people, because the music of the East can definitely be accepted and will definitely be satisfactory if they manage it themselves. ${ }^{55}$

The goal of PPRK is generally known to be that the variety [of ketimuran broadcasting?] and [its?] suitability to the Eastern soul should be held and managed by Eastern people themselves as much as possible. ${ }^{56}$

So that ketimuran broadcasting can satisfy and fulfill the desires and needs of ketimuran listeners, its programming and broadcasting have been turned over to PPRK. ${ }^{57}$

The essentialist assumption is that precisely because NIROM's Oostersche programming was not run by Asians it could never be acceptable to Asians. In this regard it is interesting to note that when PPRK finally did take over ketimuran broadcasting (in November 1940), listeners complained that it should have brought NIROM's star performers with it. In an article bluntly titled 'Why are PPRK's broadcasts bad?', the director of PPRK, Soetardjo, is reported as saying in PPRK's defense that NIROM had tied up its star performers in contracts prohibiting them from working for anyone else, and also that NIROM had reneged on a promise to transfer its entire ketimuran staff to PPRK. ${ }^{58}$ Thus he defends PPRK, which

54 It is striking how few serious arguments were advanced for why PPRK should control ketimuran broadcasting. When Soetardjo Kartohadikoesoemo first proposed PPRK to the Volksraad (Soetardjo 1936), he at least offered a pragmatic rationale. He argued that since NIROM had been dependent on the private ketimuran stations for its Eastern programming, once it cut its ties with them (as it intended to do at the start of 1937), it would have no good ketimuran material to broadcast. Therefore, he proposed, the government should support a federation of the ketimuran broadcasters themselves, independent of NIROM, since they already knew how to do it and could ensure that good ketimuran programming remained on the air. On 16 August 1938 the Volksraad approved the transfer of ketimuran broadcasting from NIROM to PPRK. Once approval was won, there was no longer a question of why PPRK should take over, only a question of when, so justifications did not need to be cogent.

55 'Seantero omroep katimoeran bisa dioeroes sendiri oleh orang-orang Timoer. Ini ada beralesan atas timbangan bahoea muzieknja katimoeran tentoe aken bisa disetoedjoei dan tentoe aken memoeasken dioeroes oleh orang Timoer sendiri' (Pewarta Soerabaia 1938a).

56 'Toedjoeannja P.P.R.K. poen oemoem ketahoein, bahoea memang soeda samoestinja kerageman dan katjotjokan pada batin Timoer dipegang dan dioeroes sendiri sabisabisanja' (Pewarta Soerabaia 1940c).

57 'Agar soepaja siaran radio Ketimoeran dapet memoeaskan dan memenoehi keinginan keboetoehan pendengar Ketimoeran, maka penjelenggaraan programma dan penjiarannja diserahkannja kepada PPRK' (Persamaan 1940).

58 'Kenapa penjiaran P.P.R.K. djelek' (Pewarta Soerabaia 1940a). A few days afterwards, two of NIROM's key performers - Koesbini, by then the director of the Surabaya studio's 
was expected to be by nature better than NIROM, by saying PPRK's problem is it doesn't have NIROM's artists and staff. ${ }^{59}$ The rhetoric of essentialism prevented people from recognizing that PPRK was simply adopting NIROM's broadcast models and practice.

\section{East vs. East}

Ketimuran radio was acutely concerned with balance and proportion. In the remarkable essay 'Taman boenga Nirom' ('NIROM's flower garden'), published in Soeara-Nirom in April 1940, fully three-quarters of the text is devoted to an extended metaphor depicting NIROM's Oostersche Programma as a garden of flowers: the various Indonesian and Asian arts are the flowers and NIROM is the gardener, whose task it is to ensure that one species does not overshadow another or crowd it out, and to coordinate the colors to make a pleasing overall view (pemandangan jang sedap daripada segenapnja).

Every plant and kind of flower needs its own plot of land and its own kind of nurturing, so as to prosper; every kind of art that comes before the microphone needs a time for broadcast and reception that is coordinated with the others, so its beauty can shine out.... That is why all of these beautiful flowers have been turned over to NIROM to be arranged in a design, so the neat and handsome garden of radio broadcasting can satisfy and delight all the groups of listeners who wish to enjoy the beauty of NIROM's garden. ${ }^{60}$

NIROM has to take care that each art has sufficient time before the microphone, and also that adding a new art to the roster does not reduce the time for others. For this reason NIROM often has to reject, with regret, the requests of listeners who ask that the broadcast time for their favorite art be extended.

house orchestra, and R. Soekarno, the group's principal male singer - published a refutation, denying that they were bound by any contract to NIROM (Pewarta Soerabaia 1940b). The reason they were not performing for PPRK, according to Soekarno, was that PPRK had opened discussions with them but then let the matter drop.

59 However questionable Soetardjo's replies, note that the attacks on PPRK began less than a month after its first broadcasts, which seems unsporting.

60 'Tiap toemboehan-toemboehan dan bangsa boenga itoe menghendaki tanah jang lain, pemeliharaan jang lain, soepaja dapat soeboer hidoepnja; tiap-tiap oesaha dimoeka microphoon, tiap-tiap boeah kesenian jang dinjatakan didepan microphoon itoe menghendaki waktoe penjiaran dan waktoe penerimaan jang selaras, soepaja terkemoekalah keindahannja. ... Maka segala boenga-boengaan jang indah dan molek itoe terserah kepada Nirom oentoek menjoesoen karangannja, soepaja taman siaran-radio jang teratoer rapi dan bagoes itoe dapat memenoehi kehendak segala golongan pendengar, jaitoe penjadap keindahan taman Nirom, dan memoeaskan hatinja sedapat-dapatnja' (SoearaNirom 1940d). 
Another difficulty lies in choosing the artists. There are many kinds of orchid, with many different colors, and therefore it is not visitors to the garden, but the professional gardener who should do the planting. On the basis of his experience, and with expert advice, he must decide which flower should be planted and where it should be placed, so the beauty of the whole garden is not diminished (terganggoe, 'disturbed'). Thus NIROM - taking into account the different and sometimes opposed interests of various social groups - has been given the responsibility to organize the many arts into a general programme for Eastern Broadcasting.

Sometimes it happens that one or another performing group thinks it has the right to appear in a certain position in the programme, and therefore it circulates a petition among listeners to strengthen its claim. But this is as though the flowers told the gardener where they should go in the garden, without regard for the overall design. Our readers will surely agree it is the gardener, namely NIROM, who must decide the place of each flower. ${ }^{61}$

Published six months before the looming takeover of siaran ketimuran by PPRK, 'Taman boenga NIROM' obviously presents NIROM's justification of its operations over the previous six years. What it doesn't say is that the principles had never worked: the flowers were constantly telling the gardener what to do. Listeners in North Sumatra requested that NIROM broadcast more Melayu music and less Javanese. ${ }^{62}$ In Surabaya they said Central Javanese court gamelan is too elevated to serve for relaxation and they much preferred the lighter East Javanese gamelan broadcasts. ${ }^{63}$ Chinese listeners in Surabaya complained that NIROM's broadcasting to the Chinese was far from satisfactory and would remain so since there were no Chinese working for NIROM; the only solution was for NIROM to set up a new transmitter and initiate an all-Chinese

61 'Ada kalanja kita lihat, bahwa sesoeatoe orkest menjangka berhak mendoedoeki soeatoe tempat jang tertentoe didalam programma, dan didalam permintaannja akan hak jang tersangka itoe orkest itoe menjangka poela lebih landjoet, bahwa permintaan itoe mesti dikoeatkan dengan daftar tanda tangan jang dikoempoelkan dengan soesahpajahnja. Boekankah jang seperti ini seakan-akan boengalah jang memberi atoeran kepada si toekang-taman tentang tempatnja didalam taman besar itoe, dengan tidak mengingatkan soesoenan segenapnja? Pembatja kita tentoe mengerti, bahwa si toekangtamanlah, jaitoe Nirom, jang mesti menentoekan tempat segala matjam boenga jang telah sedia' (Soeara-Nirom 1940d).

62 Soeara Nirom 1937d.

63 'Vorstenlandsche gamelan wordt door velen te hoog geacht voor ontspanningsmuziek. De gamelan-uitzendingen uit Soerabaja, welke gemakkelijker worden begrepen, genieten daarom een zekere voorkeur' (De Nirom-Bode 1937). 
programme staffed by Chinese. ${ }^{64}$ (Essentialism again.) Not to be outdone, an Arab-Indonesian member of the Volksraad called for a separate Arabiclanguage programme. ${ }^{65}$

These are all instances of identity politics, the box principle at work. And it hardly ended with the handover. In June 1941, well into the PPRK era, Chinese listeners in Bandung complained that broadcasting aimed at Chinese listeners had decreased by $50 \%$. They formed a committee to improve (perbaekin) PPRK's broadcasting by adding more Chinese programs. In response, pribumi listeners formed their own committee to 'defend' (membela) PPRK. The newspaper article reporting this (in a paper with a large Chinese readership) remarked that the Chinese committee was not 'anti-PPRK' (tida bersifat anti), it was simply offering suggestions for improvement, and the author hoped the misunderstanding would not lead to conflict between the races (Pewarta Soerabaia 1941b).

The radio stations themselves accepted the box principle. VORO states it succinctly:

It is inevitably the case that the Chinese want to hear Chinese music, the Arabs want to hear Arab music, the Javanese Javanese music, and so forth. Every group wants its own music. ${ }^{66}$

\section{NIROM's version:}

Melayu listeners in Sumatra certainly, we feel, prefer Melayu music and kroncong to Sundanese gamelan. And Sundanese listeners value kroncong higher than Javanese gamelan, Javanese listeners value kroncong and Melayu music more than Sundanese wayang golek, and so forth. If we broadcast Javanese gamelan, our Sundanese and Melayu listeners will say, 'Don't play too much Javanese music, because we don't understand it.' And if we broadcast wayang golek from Sunda, the Javanese listeners will say, 'Don't play too much Sundanese music, because we don't understand it at all.' And so forth. But in fact we must play all those kinds of music, because, as we all know, listeners to NIROM ketimuran consist of so many groups, whose wishes must be satisfied, even though it is not easy to do so. ${ }^{67}$

64 Soeara 'Oemoem 1939. The new transmitter should be called NIROM III, in line with the Westersche transmitter NIROM I and the Oostersche transmitter NIROM II.

65 Bafagih 1940. The Volksraad member was named Al-Djoeffry.

66 'Soedah seharoesnja, bahwa bangsa Tiong Hwa soeka mendengar lagoe Tiong Hwa, bangsa Arab lagoe Arab, bangsa Djawa lagoe Djawa dan begitoe selandjoetnja. Masingmasing golongan soeka pada lagoe-lagoenja sendiri' (Pewarta V.O.R.O. 1937d).

67 Soeara Nirom 1937c. The original text of the last sentence is: 'Tetapi toch kami MOESTI memperdengarkan lagoe-lagoe terseboet, sebab sebagai diketahoei, pendengarpendengar dari Nirom ketimoeran terdiri dari begitoe banjak golongan bangsa timoer, kemaoean siapa semoeanja haroes dipenoehi, sedangkan pekerdjaän jang demikian itoe, sebagai dapat diketahoei tidak moedah.' 
As with the east/west opposition, we cannot know whether listeners went exploring into other people's music, but we can see that the radio programmers believed they did not. East Javanese music was only broadcast to East Java, West Javanese music only to West Java, and Sumatran music only to Sumatra and Batavia, and a little bit to Surabaya. Central Javanese music was broadcast on all the stations, but the Javanese were everywhere, constituting $45 \%$ of the pribumi population of the entire colony. And, just as in the radio programming, the rhetoric of identity politics also made no allowance for crossover.

\section{One Nation, the Indonesian Nation}

So far, this investigation of radio's power to promote unity or disunity has all been about disunity. The unity comes from the prevalent forms of popular music: kroncong and Hawaiian, heard frequently on all the stations, and orkes gambus and orkes harmonium, somewhat less frequent but still widespread.

In an influential article (1986), Tsuchiya Kenji proposes that kroncongbecause of its supposed origins in the music of Portuguese slaves and subsequent adoption by Eurasians and Indonesian seamen and the stambul theater, itself dominated by Eurasians - belongs to no particular culture but is inherently mestizo, and moreover that it stirs up feelings of melancholy and nostalgia in the hearts of its listeners that embod[y] neatly [the] amorphous 'mestizo' situation in 19th-century Java.' He goes on to say that kroncong on the radio 'made even deeper inroads in Javanese society and [was] often combined with the melody of native Javanese music. ${ }^{68}$

Tsuchiya's main topic is Raden Adjeng Kartini, and I am in no position to dispute his conclusions about her. But I think he has kroncong all wrong. Kroncong was not on the whole melancholy. ${ }^{69}$ Rather it was, up until

68 The one melody? Tsuchiya is probably thinking of langgam jawa, a genre using the instrumentation of kroncong but whose hundreds of melodies were in a scale approximating the pelog tuning of Javanese gamelan music - but langgam jawa did not emerge until the 1950s. There was, however, a now-obscure 1930s precursor of langgam jawa known as kembang kacang, using kroncong instrumentation and a quasi-pelog scale. I have seen no indication that the genre had a presence on radio or gramophone records before the war, though a tune with the title Kembang katjang is included in some kroncong broadcasts.

69 There was one infrequently played minor-key melody, Kroncong Bandan, that was reserved for laments of the poor-me variety; and occasionally other kroncong melodies would be used for lovesick lyrics, but these cannot justify a characterization of the whole genre as melancholy. Neither can Tsuchiya's melancholy be located in kembang kacang (if he knew about it at all). Koesbini ([=Kusbini] 1972:34) reports that kembang kacang was happy and was interspersed with humor (gembira, berseling humor). 
about 1917, an up-tempo, melodically limited vehicle for banter in the pantun verse form; and after that it was most likely to be romantic, cheery, or mood-neutral. It was not the music of no culture, it was by the end of the nineteenth century the urban folk music of Batavia, and from there it entered the musical repertoire of the stambul theater. Nobody really knows what kroncong was before the 188 os, but by that time, when it begins to surface in the historical record, it was very much the music of one specific group, the Eurasians of Batavia, and perhaps also the peranakan Chinese. And from the 1920 s on it became a popular music, disseminated to cities everywhere in the DEI on gramophone records and radio. For reasons I have explored elsewhere (Yampolsky 2010), over the course of the 1930s kroncong became increasingly Westernized, abandoning both its characteristic accompaniment idiom and the traditional pantun stanza form of its lyrics and instead adopting dance-band arrangements (rumba, tango, foxtrot, waltz).

It is going much too far to imply - as one would have to do in order to reconcile my view with Tsuchiya's - that popular music is ipso facto mestizo. Popular music often crosses boundaries - of geography and culture, perhaps, to unite people by generation rather than by ethnicity - but it does not erase those boundaries. That is what the formidable presence of gamelan, tembang Sunda, wayang, macapat, ludruk, and kethoprak on the radio in 1938 shows us: the boundaries were there; the Javanese desire to hear Javanese gamelan and wayang kulit and kethoprak, the Sundanese desire to hear tembang Sunda and wayang golek had not eroded. Kroncong, precisely because it was sung in the lingua franca and was not linked to a specific region or ethnicity, may well have offered a relief from the confinements of cultures, a vision of a wider world; but it did not miscegenate genres.

What it did, rather, was to place within a Western instrumentation and an increasingly Western musical idiom lyrics relating to Indonesian life and sung in the Indonesian lingua franca. Hawaiian went further in the same direction: with lyrics in English (or Hawaiian) and, again, a foreign musical idiom, it moved out of Indonesia completely - except for the fact that it was played in Indonesia by Indonesians. ${ }^{70}$ Gambus and harmonium broadcasts straddled boundaries: the songs were for the most part sung in Arabic, but the playlists always included lagoe extra Melajoe (Melayu

70 This observation applies to Hawaiian before the emergence of langgam Hawaii (footnote 42). 
extra songs) in Indonesian, and the musical idioms of these broadcasts shifted between the Middle East for the Arabic songs and a Malay/MiddleEastern/Western mixture for the extras. The appeal was to Muslims of all ethnicities, and to speakers of the lingua franca.

Thus kroncong, Hawaiian, and the Arabic-language repertoire of gambus/harmonium were all supra-ethnic and supra-regional - in fact, to some extent, international. In their lagoe extra Melajoe, gambus and harmonium were not quite supra-ethnic, inasmuch as some of these songs were associated with the Melayu ethnic group, but they were nearly so, since the mother tongue of that group was the lingua franca; and they were fully supra-regional, since the Melayu were the least regionally bound of all Indonesian ethnicities, with sultanates established from Malaya and Aceh to British North Borneo and Maluku.

Today, in the twenty-first century, Indonesian society is so fragmented that no form of expression tied to one ethnic or regional group can be accepted by any other groups as representing them. (For example: although Javanese batik is an internationally recognized symbol of Indonesian culture, a batik national flag would be unthinkable.) The situation was the same in the early years of the twentieth century, when first gramophone and then radio were introduced to the colony. These media adapted to the fragmentation by trying to serve all of the principal ethnic groups. But the strongest impulse of mass media is to maximize the audience, to market to the mass, and since no ethnically or regionally delimited music could serve as a mass Indonesian music, it was necessary to adopt symbolic forms free of such linkage: forms tied to no particular place within Indonesia, or forms from outside Indonesia altogether. Popular music in foreign musical idioms and instrumentation and sung either in a foreign language or in Indonesian was one such form; music associated with a world religion like Christianity or Islam was another. ${ }^{71}$ This is in large part, I believe, what accounts for the prominence in 1938 of kroncong, Hawaiian, orkes gambus, and orkes harmonium alongside all the gamelan, wayang, and tembang.

Once PPRK took over siaran ketimuran, the role of kroncong in creating a mass audience acquired a political interpretation. PPRK's first highprofile live event, variously billed as a concert of Indonesian folk

${ }^{71}$ Still today, the only musics that have a pan-Indonesian audience are, on the one hand, the various kinds of Indonesian-language popular music, all of which use Western instrumentation and elements of Western idiom, and, on the other, music associated with Islam or, to a lesser extent, with Protestant and Catholic Christianity. 
music (Volksconcert Indonesia) and a performance of Eastern art (pertoendjoekan kesenian Timoer), was a concert held in the Schouwburg in Batavia on 11 January 1941 and nominally devoted to kroncong, which Soetardjo described in his opening speech as a kind of music 'enjoyed (digemari) by almost all the Eastern people who live in these various islands.' (The definition of kroncong was sufficiently loose by then that the concert probably included other types of popular music as well, as did the radio broadcasts itemized in Playlists 8, 9, and 10.) The groups performing were Krontjong Orkest The Golden Star, Krontjong Orkest Lief Java, and the PPRK Radio Orkest. Lief Java wore Javanese dress; the Radio Orkest wore dinner jackets. Miss Roekiah, Miss Ijem, and Miss Soelami sang in the concert, and the comedian known as Botol Kosong (Empty Bottle) also performed. ${ }^{72}$

In the very first issue of PPRK's program guide Soeara Timoer, covering the two weeks ending with that concert, one of the editors, Hamid Algadrie, published a manifesto titled 'PPRK and Indonesian culture,' which proclaims that

Indonesian society has only recently arisen from sleep. It has been a static society but is now moving to become a dynamic one; it is an Eastern society that has just 'married' with Western society and has not yet produced the child that will, when it is grown, be Indonesian culture in the true sense, namely a culture that can be understood by every member of Indonesian society, and that contains an active spirit!

In our view, this is PPRK's primary duty: to aid in forming this Indonesian culture for the future, and to ensure the success of the 'marriage' between Eastern and Western culture, so our society and culture do not become something unproductive, 'between two worlds, the other powerless to be born,' as in a wrong marriage, one that cannot produce healthy offspring. ${ }^{73}$

72 Soetardjo's speech was published in Soeara Timoer 1941. The details of the performers' dress and the names of the soloists come from Boediardjo $1941 \mathrm{~b}$.

73 Soeara Timoer 1940-41. 'Masjarakat Indonesia adalah satoe masjarakat jang beloem beberapa lama bangoen dari tidoernja, satoe masjarakat jang statisch jang sedang menoedjoe ke masjarakat jang dynamisch, satoe masjarakat Timoer jang baroe 'menikah' dengan masjarakat Barat, jang beloem dapat melahirkan anak, jang, djika dewasa, akan meroepakan keboedajaan Indonesia, dalam artian kata jang sesoenggoehnja: jalah keboedajaan jang dapat difaham oleh tiap-tiap anggauta dari masjarakat Indonesia dan keboedajaan jang mengandoeng djiwa jang bergerak! [The words in italics here are all caps in the original.] [Paragraph] Sekedar pemandangan kita disinilah terletak kewadjiban P.P.R.K. jang teroetama: membantoe membentoek keboedajaan Indonesia jang satoe oentoek hari kemoedian dan mendjaga berhasilnja 'perkawinan' diantara keboedajaan Timoer dan Barat, soepaja masjarakat dan keboedajaan kita tida meroepakan sesoeatoe 
Algadrie did not specifically name kroncong as the child of East and West that would usher in a true Indonesian culture, and Soetardjo in his opening speech did not claim more for kroncong than that it was widely enjoyed. But commentators recognized instantly that PPRK was proposing kroncong as a moesik persatoean, a 'music of unity' that could appeal to all Indonesians. The well-known polemic in the journals Poedjangga Baroe and Kritiek en Opbouw on 'kroncong vs. gamelan' turns on this point. ${ }^{74}$ Ali Boediardjo (1941b) started it off by attacking the 11 January concert as an 'American-style show' (show tjara Amerika) and stating that he was appalled that PPRK was offering kroncong as an example of art (kesenian). But, he said, the concert raised a more important question: what should be the unifying music of Indonesia (moesik manakah jang akan didjadikan moesik persatoean Indonesia)? Not, in his view, kroncong'that mix of false and shallow romance, that mix of imitation American jazz and showbiz,' that 'shadow' (bajangan) of European music - but Javanese gamelan, a music of refinement, delicacy, grandeur, and joy. Boediardjo concedes, however, that gamelan music may be too refined for modern Indonesian society; but it has the capacity to change, perhaps by incorporating Western elements, perhaps not.

To which Armijn Pané replied (1941a:257), 'Apparently [Boediardjo] forgets that there are people from Sumatra, Manado, or Ambon, who do not find the atmosphere of gender and slenthem [gamelan instruments] appealing.' Even if they can appreciate it, as Pané himself (a Sumatran) does, they don't think it's the highest pinnacle of culture. Pané admits that kroncong in the past was shallow, but now - perhaps as a result of radio's influence, he suggests - it has more content. (However, all he seems to mean by this is that the formulaic words and syllables formerly used to fill out a verse line and make it fit the melody were now eschewed by songwriters as amateurish.) And because it is enjoyed by all groups (not just one, like Javanese gamelan), it fulfills one of the requirements for a unifying music (memenoehi salah satoe sjarat moesik persatoean). That is why PPRK, wanting to satisfy all groups, chose to devote its first concert to kroncong. Pané ends his

jang onproductief, between two worlds, the other powerless to be born, sebagi satoe perkawinan jang salah, tak koeasa melahirkan toeroenan jang sehat.'

The English phrases in the second paragraph are an incomplete quotation from Matthew Arnold's 'Stanzas from the Grande Chartreuse,' in which the poet speaks of himself as 'Wandering between two worlds, one dead, / The other powerless to be born.'

74 The key articles in the polemic are: Boediardjo 1941a in Dutch; its Indonesian translation, Boediardjo 1941b; and Armijn Pané 1941a and 1941b. Other contributions are Resink 1941 and Brandts Buys-Van Zijp 1941. 
article by saying that 'just as there is, alongside the regional languages, the Indonesian language, so also with music: alongside the regional musical arts such as Javanese, Sundanese, and Balinese gamelan, etc., it must be admitted that there is a music of Indonesia in general [moesik-Indonesia oemoem ], namely kroncong' (Pané 1941a: 260).

But this political spin on kroncong was, in 1938, still in the future. By forming a mass audience of listeners, radio can be said to have shaped an Indonesian public, but I think it anachronistic to say that in 1938 this public had an Indonesian consciousness. It was instead, I believe, a consciousness directed towards entertainment, and ultimately towards consumption. And even in 1941, kroncong and popular music in general may have been becoming a musik persatuan by virtue of their wide appeal, but I see little indication that they were acquiring political content, that they had anything to say about what Indonesia should be. It took the Japanese occupation and the resistance to recolonization by the Dutch to give the audience formed by media, the consumers of entertainment, a political, national purpose.

\section{A Digression on Nationalism}

The word Indonesia was officially banned on the air in the DEI until 8 January $1942 .{ }^{75}$ At that time, the Procureur-Generaal wrote to PPRK saying it was now permitted to broadcast speeches and songs containing the word. Indonesia Raya, however, was still banned, because it was classified not as a song (njanjian) but as a national anthem (lagoe kebangsaan) (Soeara Timoer 1942).

Although songs may have been excluded from the airwaves because of government warnings or self-censorship on the part of the stations themselves, I know of only one recording, aside from Indonesia raya, that was banned from circulation. This was Brani kerna benar, recorded by S. Abdullah and released in November 1936. In late January 1937 the police went after it, seizing copies in record stores and banning future sales. ${ }^{76}$ Here are the lyrics.

75 Soeara Timoer 1942. But notice Playlist 20 from 1938, where it slipped in. Perhaps the ban was not carefully enforced.

76 Sinar Pasoendan 1937a, 1937b. The second article helpfully provides the song lyrics, for anyone who failed to snare a copy of the record before the stock was seized. 
Brani kerna bener / Be brave because you're in the right

Foxtrot Krontjong - HMV NS 131, issued November $1936^{77}$

S. Abdullah \& the H.M.V. Batavia Orkest

Asal sendiri merasa benar,

Djanganlah moendoer atawa keder,

Maski moesoehnja besar dan angker,

Lawanlah teroes djangan meliker [=melingker $]$

Maski apa akan mendjadi,

Madjoelah teroes djanganlah djeri,

Oendjoek dirimoe sebagai laki-laki,

Boeat membela kebenaran sedjati.
So long as you feel you're in the right,

Don't retreat or lose your way.

Even though your opponent is big and frightening,

Keep on opposing, don't turn away.

Whatever will happen,

Press forward, don't be afraid.

Show your manliness,

To defend what is truly right.

If these lyrics were enough to bring out the police, think how innocuous everything else broadcast and sold without interference must have been! To see 1930s kroncong, or 1930s radio and gramophone in general, as a nationalist force is, I believe, just wishful thinking. ${ }^{78}$

\section{Modern Music}

And, finally, what about modernity, a central theme of the present volume? Here are instances of how the word modern is used in reference to DEI radio music.

Modern (the word itself, untranslated) occurs frequently as a descriptor in the program guides, seemingly serving as part of a performing group's

77 Here and elsewhere in this chapter, release dates and other discographical details come from my discography-in-progress of pre-war gramophone records issued for the DEI, Malaya, and Straits Settlements. Song lyrics come from HMV record catalogues or from paper sleeve-inserts issued with the records. The translations into English, admittedly rough, are my own.

78 Citing Tsuchiya, Mrázek (2002:180) writes: 'The radio ... helped the kroncong to become the dominant Indonesian national, indeed nationalist music.' Tsuchiya (1986:82, n.8) doesn't phrase it quite this way. He says that through radio 'kroncong melodies made even deeper inroads in Javanese society', and, further, that 'in the process of Indonesia's fight for independence from Japan's military rule, kroncong became popular in songs inspiring a nationalistic spirit'. Both statements are correct, but Mrázek has not situated them properly in time. The 'deeper inroads' were made in the years up to 1942, years when kroncong was purely entertainment music. It is true that during the Japanese occupation (1942-1945), and especially during the Indonesian Revolution (1945-1949), kroncong songs became a medium for expressing the spirit of resistance and nationalism. But that came about because the Japanese banned the Western popular songs and popular idioms that had increasingly infused kroncong since 1930 and by 1942 had, I believe, rendered kroncong passé. Kroncong was revitalized and, so to speak, re-Indonesianized by the ban, and that is when it became available for nationalist content. 
name (though I suspect it may sometimes be a descriptive insertion by the editors rather than the musicians):

- Modern Harmonium Orkest 'S. M. Alaydroes'

- Gamboes Orkest Modern 'Rozen'

- Modern Gamboes Orkest 'Al Wardah'

- Orkest Melajoe Modern [Modern Melayu Orchestra] 'Penghiboer Hati'

- Orkest Melajoe Modern 'Sinar Sumatra'

- Krontjong dan Modern Gambang Kromong Orkest 'Sinar Kramat'

- Orkest Tiong Hwa Modern [Modern Chinese Orchestra] 'The Bright Stars'

- Modern Javaansch Tooneelgezelschap [Modern Javanese Theater Company] 'Sri Moeljo Koentjoro' (this was a kethoprak troupe).

Or it may be used to describe the kind of music to be broadcast:

- 'modern kacapi music' (ketjapi modern, played by Soehji Soebandi or Soelaiman)

- 'modern Chinese tunes' (lagoe Tiong Hwa modern, unnamed group)

So what does modern mean in reference to music on the radio? What does the descriptor indicate?

In application to the instrumentation of a performing group the meaning is clear: 'modern instruments' (perkakas modern, boenji-boenjian modern, alat-alat modern) are always European instruments. ${ }^{79}$ Entries from the program guides demonstrate this repeatedly:

- The Strijkorkest [string orchestra] Pandowo performs 'Central Javanese music with Western instruments [lagoe Djawa-tengah dengan instrumenten Barat]. The times have changed, and the art of instrumental music must also change. And so: Central Javanese music with modern instruments.' Another reference to this ensemble, some years later, states that the modern instruments (alat boenji-boenjian modern) include 'violin, guitar, cello, etc., to replace the gamelan' (oentoek penggantigamelan). ${ }^{80}$

79 The idea of 'modernizing' a traditional instrument - developing gamelan instruments that play European major/minor scales, for example - does not arise in the program guides.

80 The first quotation is from Soeara Nirom 1937f: 'Zaman telah beredar dan berganti, demikian poela matjam kesenian boenji-boenjian djoega menghendaki perobahan: Lagoe Djawa-tengah dengan instrumenten, jang modern.' The second, listing the instruments, is from Soeara-Nirom 1940f. 
- The Orkest Ketjapi 'Poerwakanti' - which would seem, from the name, to be a Sundanese ensemble of plucked zithers (kacapi) plus a bowed lute (rebab) or flute (suling) - 'is not like the usual kacapi ensemble. Instead, apart from the kacapi themselves, the instruments are all modern [perkakas moesiknja serba modern]. Instead of the rebab, there is a violin ... and there is a plucked cello.'81

- A photograph of the Orkest Tiong Hwa Modern [Modern Chinese Orchestra] 'The Bright Stars' shows guitar, string bass, accordion, violin, saxophone, and, indistinctly, what might be a trumpet. No traditional Chinese instruments are evident (Soeara-Nirom 1939b).

- A photograph of the Orkest Modern Al-Ittihad, which plays 'modern Arab music,' shows three guitars, violin, double bass, ukulele, tambourine, trumpet, and harmonium (Soeara-Nirom 1940b).

- A photograph of the Orkest Soeling Modern daripada Kepandoean Arab 'Al Irsyad' (the Modern Flute Orchestra of the Arab Scout Troupe 'Al Irsyad'), from Surabaya, shows a group of boys in scouting uniforms, with a boy conductor in front. The instruments are side-blown bamboo or wooden flutes (these were introduced into Indonesia by missionaries in the 19th century) plus two guitars and a sit-down drum kit (bass drum, two snare drums, and a wood block) (Soeara-Nirom 1939c).

- In reference to the Orkest 'Minangkabau Saio': 'In order to fulfill the demands of Minangkabau art, so that it should not be too hard-pressed [terlaloe terdesak] by modern music and instruments [alat dan lagoe modern], tuan Rozen Bahar, the director, has brought from West Sumatra two master musicians.' They play traditional Minang instruments: rabab (bowed lute) and salung (saluang, an oblique flute) (Soeara-Nirom 1940c).

- The Orkest 'Nam Fong' will play 'modern Chinese music with modern and old-style instruments [perkakas modern dan asali].' A photograph of the ensemble shows Chinese instruments (yangqin, sanhsien, erhu, and hsiao), plus two violins and a guitar (Soeara Nirom 1939a). Guess which instruments are the modern ones?

In application to style and repertoire, the meaning of modern is more complicated. Not surprisingly, it is often contrasted with terms denoting

81 Soeara-Nirom 1940b. The description specifies that the cello is not held upright but is instead placed horizontally across the player's lap, and that it is 'not only plucked but also struck with the palm, making a thrumming sound [mendengoeng] like a gendang [the kind of drum used in Javanese and Sundanese gamelan].' The 'cello-drum' sound was also a feature of kroncong from at least the mid-1920s. 
the past, such as lama, koeno, asli, and origineel, ${ }^{82}$ and linked instead with the ideas of youth, newness, and the present:

Among the Arabs [in Batavia], many of the young people prefer modern songs to old ones [lagoe modern dari pada lagoe koeno]. The same is true among the Chinese (Pewarta V.O.R.O. 1937a).

It seems that English has become the language of our young people. Everywhere and all the time they sing in English. Their parents sometimes become annoyed at them, because their older ears are tuned and suited only to grand and weighty old-style music [moesik lama, jang alamat dan berat itoe]. Parents dearly wish to see their children pay more attention to their own culture [i.e., rather than foreign culture]. Older people cannot adjust their sensibility and their listening to the commotion [kebisingan] found in all modern songs and instrumental music, nor to the extreme behavior of young people reflected in the songs. Kroncong, gamelan, kacapi, rebab, salung, and suling remain the sounds old people love. ${ }^{83}$

The existence of contrasting modern and old-style versions of a genre in the repertoire of a single performing group is frequently mentioned in the program guides: ${ }^{84}$

82 The Indonesian equivalent of origineel is asli; it is defined in dictionaries from the 1930 and '40s as 'original,' but in most cases in Indonesian music no one knows what the original repertoire or style actually was. One knows only what people did within living memory, or what is thought to have been earlier practice. This is why I typically prefer to translate both origineel and asli as 'old-style,' or, in some contexts, 'traditional.' As for the other antonyms of modern: lama means 'old,' and kuno ranges in meaning from 'old' back through 'archaic' to 'ancient.'

83 Here is the original text of this interesting passage (Soeara-Nirom 1940i): 'Maka serasa bahasa Inggeris itoe telah mendjadi bahasa pemoeda kita seoemoemnja. Dimana sadja dan bilapoen mereka menjanjikan njanji dalam bahasa Inggeris selaloe. Maka orang toea mereka kadang-kadang djadi kesal memikirkan itoe, sebab pendengaran telinga orang toea itoe masih selaras dan hanja sesoeai dengan soeara moesik lama, jang alamat [see below] dan berat itoe. Orang toea itoe ingin sekali melihat anaknja lebih banjak menoedjoekan perhatian akan boeah keboedajaan sendiri. Orang toea itoe tidak dapat menjesoeaikan per[a]saan dan pendengarannja kepada kebisingan jang terkandoeng didalam segala lagoe dan moesik modern, dan djoega akan ketelandjoeran pemoeda jang terbajang didalamnja. Krontjong, gamelan, ketjapi, rebab, saloeng dan soeling masih mendjadi alat boenji-boenjian jang masih digemari sangat.' This is an old use of alamat that does not appear in today's dictionaries (e.g. Stevens and Schmidgall-Tellings, or the Pusat Bahasa dictionary of 2008). It is found, however, in Iken and Harahap's Kitab arti logat Melajoe (1940:14), which gives kehormatan, kemegahan, and kebesaran as a second group of meanings after the current senses of 'street address,' 'sign,' etc.

84 On the other hand, some groups play only the modern or only the old-style version of a genre; and some genres have only one form on radio. In the case of Javanese and Sundanese gamelan, for example, the term asli frequently appears in conjunction with gamelan broadcasts, but modern never does, except in reference to instrumentation when the music is transferred to European stringed instruments (as with the Strijkorkest 
- 'Krontjong-Orkest 'The Melody Band' ... presents a variety of kroncong and stambul songs, both old-style [origineel] and modern' (Soeara Nirom 1938a, entry for 9 January; cf. Playlist 9).

- 'Alongside lagoe Tapanuli lama [i.e., old songs from the region of northern Sumatra known as Tapanuli, the homeland of the Toba Batak], various kinds of modern Tapanuli songs have emerged, as will be heard in the broadcast by Batak Hawaiian Tapian Na Uli (SoearaNirom 1940a).

- Hoa Kiauw, a gambang kromong ensemble, 'presents modern and oldstyle gambang kromong [lagoe gambang-kromong modern dan asli]' (Soeara-Nirom 1940h).

What then makes a genre, or a version of a genre, modern? Instrumentation alone does not do it, since it is possible to have a traditional repertoire played on Western instruments (Strijkorkest Pandowo and Orkest Ketjapi Poerwakanti, above), and to have a modern repertoire played on a traditional instrument (kacapi modern, discussed below). I propose that in the discourse of DEI radio it is the incorporation of elements of the European and American ('Western') popular music of the 1920s and '3os that qualifies a music as modern. The elements may be specific popular songs, or, more generally, dance rhythms, song forms, the common-practice harmony, or the accompaniment idioms and arrangement styles of Western popular music.

Consider the following genres, all characterized in the program guides either as wholly modern (e.g. 'modern Chinese music') or as having both a modern and an old-style repertoire:

- Kroncong and stambul. As quoted above, The Melody Band offers both origineel and modern kroncong and stambul. The difference is one of both idiom and instrumentation: old-style kroncong and stambul used a string band of violin, small lutes, and cello, and a distinctive accompaniment idiom, while the modern songs of the 1930s expanded the instrumentation (already 'modern,' in that the instruments of the old style were Western) to include dance-band instruments (clarinet, trumpet, saxophone, piano, etc.), and they adopted dance-band idioms: jazz, blues, swing, rumba, tango, foxtrot, beguine, and so forth. When these

Pandowo above). Gamelan was inevitably 'traditional,' and asli appears in the programguide descriptions not to contrast the asli form with a modern one, but to contrast gamelan music with all the modern music around it on the radio. Hawaiian is another genre with only one form: there was no asli version, so 'modern' is not needed in the descriptions. 
idioms were applied to compositions in the specific structures of kroncong and stambul, the results were kroncong tango, kroncong blues, etc., collectively called kroncong modern.

- Sundanese kacapi ensembles. Two performers, Soehji Soebandi and Soelaiman, regularly appeared (individually) on NIROM playing the Sundanese kacapi or plucked zither. Their programs were called ketjapi (=kacapi) modern. The genre title contrasts implicitly with the very frequent broadcasts by one or another kacapi orkest, which presented the much-loved genre of tembang Sunda, discussed earlier in connection with Playlists 5, 6, and 7 .

The contrast is implicit because, for some reason, tembang Sunda was not characterized in the program guides as asli. ${ }^{85}$ Tembang Sunda was sung entirely in Sundanese and was accompanied only by the traditional instrumentation of one or more kacapi plus a flute (suling) or a bowed lute (rebab). What made the kacapi modern broadcasts modern was not the instrumentation, since both musicians are described as playing the kacapi, but the repertoire. Playlist 13 shows one of Soebandi's broadcasts: five tunes with English titles (including Shirley Temple's signature song, On the good ship Lollipop) and one with a Hawaiian title (Oea-oea, the opening piece for all of Soebandi's broadcasts, which suggests that his kacapi may have imitated the sound of a Hawaiian guitar in some numbers). Others of his broadcasts included La paloma and Bei mir bist du schön; there was not one with even an Indonesian - let alone a Sundanese - title.

The other kacapi modern performer, Soelaiman, was one of the directors of the Ketjapi Orkest 'Margaloejoe,' which played traditional tembang Sunda repertoire (though its programs were less formal than those shown in Playlists 5, 6, and 7). On his own, however, in the kacapi modern broadcasts, Soelaiman played mainly pieces with Indonesian (not Sundanese) titles, and he included melodies totally outside the tembang Sunda repertoire, such as Terang boelan (Miss Roekiah's film hit, a Western-idiom popular song) and the Batavian popular tunes Djali-djali and Tjantek manis, presumably arranged in a Western idiom.

85 I speculate that the reason tembang Sunda on the radio is not called asli is that panambih had already become so prominent that the 1930s style of performance was felt to be a newer, modified form of the genre. Playlist 5 , for example, with one tembang paired with one panambih, clearly gives a greater share of the performance to panambih than more classical programs like those in Playlists 6 and 7 , where one panambih follows a group of tembang. So the 1930 form was already not asli-but it was not modern, because it had not yet assimilated significantly to Western or Indonesian popular music. 
- Chinese music (lagu Tionghoa). Playlist 14 shows a broadcast by the Orkest Tionghwa Modern [modern Chinese orchestra] 'The Bright Stars.' This is the same Chinese-music ensemble whose instruments (guitar, string bass, accordion, violin, saxophone, trumpet?) were listed above. In its broadcasts, the group always played 'modern Chinese music' (no contrasting old-style tunes were indicated), plus a number of extras, usually with titles in English. In this broadcast, six of the extras were taken from a 1937 American movie, The singing marine, starring Dick Powell. In other broadcasts by this group, the extra songs included I'm Popeye the sailor man, Pennies from heaven, Tiger rag, and Kicking the gong around. I am not able to assess the Chinese-language titles, but the Western instrumentation of the ensemble, as well as the juxtaposition of Chinese songs with English-language ones, strongly suggest that they came from the realm of Western-idiom Chinese popular music. If so, then - just as kacapi modern was contrasted with tembang Sunda - they are implicitly contrasted with the Chinese traditional music heard in yang kim or pat im broadcasts.

- Batak music (lagu Batak). Toba Batak traditional music - typically instrumental and sounding quite unlike the music of a Western string band or dance band - was never, so far as I know, broadcast on DEI radio, and certainly not in 1938 on the stations I deal with here. Batak music on the radio and on gramophone records was newly composed; it focused on singers and consisted of duets and choruses, tangos and rumbas in the standard Western harmonic idiom. (Cf. the quotation above concerning the Batak Hawaiian Tapian Na Uli group. Note the 'Hawaiian' in the group's name.)

- Melayu music (lagu Melayu), Harmonium, Gambus. I must be more tentative when we come to these three genres. More work needs to be done to assess the differences among them and the extent to which their explicitly modern forms (Melayu modern, gambus modern, and modern harmonium) embraced Western popular music.

I include sample playlists of their modern-form broadcasts as Playlists $15^{-20}$. Only one piece comes unequivocally from the West: the instrumental tango A media luz in Playlist 15. (The second instrumental in that broadcast, Salome, probably does as well.) The other titles are in Arabic and Indonesian. Are the Arabic titles rumbas and tangos, as they often are on those DEI gramophone records of the period that are sung in Arabic? (Remember the rumbas in Playlist 3, broadcast by a gambus orchestra not designated as modern: even the ordinary gambus groups were playing Western dance music.) And the Melayu titles - are these 
ordinary urban popular songs in Western idioms, or are they performed in the heterophonic unharmonized idiom of traditional Melayu Deli music?

My supposition is that when Playlist 16 says the broadcast will include 'popular songs' (lagoe-lagoe jang populair), it means songs drawn from the Westernized repertoire omnipresent on the radio, not from a separate and narrower repertoire of Melayu-idiom popular song. Corroboration seems to come from a 1939 program-guide entry for the

PLAYLIST 13. KACAPI MODERN

Ketjapi modern, dimainkan oleh Soehji Soebandi. [Modern kacapi, played by Soehji Soebandi.]

NIROM Oostersche Programma (Batavia/Bandoeng), 7 September 1938, 11:30-12:00.

Oea-oea

Alone

Tina

Happy Days

On the Good Ship Lolly-pop

Little Man

\section{PLAYLIST 14. MODERN CHINESE}

Orkest Tiong Hwa modern "The Bright Stars" atawa "Bing Sing," dipimpin oleh toean Tan Soen Han di dalam Studio NIROM, memperdengarkan matjammatjam lagoe Tiong Hwa modern. [The modern Chinese Orchestra "The Bright Stars" or "Bing Sing," directed by tuan Tan Soen Han in the NIROM Studio, presents various modern Chinese tunes.]

NIROM Oostersche Programma (Soerabaia), 23 August 1938, 20:00-22:00.

[Ten tunes with Chinese titles, transliterations sic in the program guide]:

Siauw Siauw Moo Lie

Tjhwee Bauw Bauw

Tjwee Hoo Ti I Oe

Nie Yauw Djang Koo

Mai Pauw Koo

Yauw Lan Tjhih

Yen Tjhwen

Tjin Tjoeng

Sin Mao Mao U

Ta Ti Sin Tjwin Tjhih 


\section{Extra's:}

Song-hits from the The singing Marine [movie, 1937]:

The Song of the Marines (steps)

'Cause My Baby Says It's So (fox-trot)

You Can't Run Away from Love (slow-fox)

The Lady Who Couldn't Be Kissed (fox-trot)

Night over Shanghai (fox-trot)

I Know Now (slow-fox)

Hoor Mijn Lied, Violetta (tango)

Lulu's Back in Town (fox-trot)

Some Fiddlin' (violin solo)

Here Come the British (fox-trot)

PLAYLIST 15. MELAYU Modern

Orkest Melajoe Modern "Sinar Sumatra," dipimpin oleh toean Moehamad Noerdin. [Modern Melayu Orchestra "Sinar Sumatra," directed by tuan Moehamad Noerdin.]

NIROM Oostersche Programma (Batavia/Bandoeng), 12 August 1938, 20:00-22:00.

Opening marsch

Bersenang Hati

Boeroeng Tjamar

A Media Luz (muziek [=instrumental])

Rindoe

Lagoe Dana

Ranoengan Kalboe

Salome (muziek [=instrumental])

PLAYLIST 16. MELAYU MODERN

Orkest Melajoe Modern "Penghiboer Hati," dipimpin oleh toean St. Perang

Boestami, dinjanjikan oleh Nona Siti Priwati dan Boeng Sjaugie. [Modern

Melayu Orchestra "Penghibur Hati," directed by tuan St. Perang

Boestami, with singers Nona Siti Priwati and Boeng Sjaugie.]

NIROM Oostersche Programma (Batavia/Bandoeng), 4 September 1938, 23:00-24:00.

Lagoe Pemboeka'an

Sambil Berbaring

Wangkang Petjah

Anak Dagang

Nasib Rabihatoen

Seri Sambas

ditambah dengan lagoe-lagoe jang populair [plus popular songs] 


\section{PLAYLIST 17. MELAYU MOdERN}

Orkest Melajoe modern dipimpin oleh toean August Oedin, dengan soeara dari Siti Rohana. [Modern Melayu Orchestra, directed by tuan August Oedin, with Siti Rohana, singer.]

NIROM Oostersche Programma (Batavia/Bandoeng), 25 May 1938, 23:0024:00.

Pemboeka'an: Turksch Marsch

Air Mawar Toempah

Serantih

Laili Madjenoen

Nasib Rabihatoen

Boeroeng Poetih

Penoetoep: Nina Bobok

\section{PLAYLIST 18. MODERN HARMONIUM}

Modern Harmonium Orkest "S. M. Alaydroes."

NIROM Oostersche Programma (Batavia/Bandoeng), 23 August 1938, 21:3023:30.

\section{S. M. Marsch}

Menoentoet Ilmoe

Agisbis Mata Sjita

Pasar Gambir Didirikan

Bandar Negeri

Kaoem Iboe

Mata Jakiran

Gamboes Singapo[e]ra

Jahabiboelgalbi Silni

Tanah Periangan

Penoetoep

PLAYLIST 19. MODERN GAMBUS

Modern Gamboes Orkest "Pemoeda," dipimpin oleh toean H. Moh. Jasin Aldjawi.

[Gamboes Orkest "Pemoeda," directed by tuan H. Moh. Jasin Aldjawi.]

NIROM Oostersche Programma (Batavia/Bandoeng), 12 December 1938, 22:30-24:00.

Aldjawi Marsch

Siaran Betawi

Lenggang Melenggang

Kasidah Lilazzatoun

[title not given] 
[title not given]

Kasidah Jagoellama

PLAYLIST 20. GAMBUS [not explicitly "modern," but playing "the newest Arab and Melayu songs"]

Gamboes Orkest "Pemoeda," jang dipimpin oleh toean H. M. Jasin All Djawi [=Aldjawi] memperdengarkan lagoe-lagoe Arab dan Melajoe jang paling baharoe. [Gamboes Orkest "Pemoeda," directed by tuan H.M. Jasin All Djawi, presents the newest Arab and Melayu songs.]

NIROM Oostersche Programma (Batavia/Bandoeng), 9 June 1938, 20:0022:00.

Assalamoealaikoem

Ala Ja' Aini Djoed

Lahmin Ha

Intermezzo

Boeahnja Poelau Djawa

Di Indonesia

Intermezzo

Allaj Loe Feraum

Agistoe Fi Manami

Agallili

Intermezzo

Nasibnja Jasin All Djawi

Terang Boelan di Poelau Djawa

Orkest Melajoe Modern 'Sinar Sumatra': '[The group's] Melayu songs are played with all modern instruments. But that is not all! The lyrics of modern Western songs are translated into Malay.... [The director] always tries to serve up the songs currently most favored by listeners in general.' ${ }^{86}$ If the words were translated from Western songs, it seems highly likely the music itself was also Western.

To sum up, the essential procedure for making an Indonesian (or Chinese, or Arabic-language) music modern was to fuse it, in one way or another, with Western popular music. The striking point here is the equation of modern with popular, and hence with mass media, the indispensable

86 'Lagoe2 Melajoe dimainkan dengan perkakas jang serba modern. Boekan itoe sadja artinja penjiaran ini! Dari lagoe2 Barat jang modern perkataannja diterdjamaähkan kedalam bahasa Melajoe. Toean Mohamad Noerdin, pemimpinnja, senantiasa beroesaha melajankan lagoez jang pada saät ini sangat digemari oleh pendengar seoemoemnja' (Soeara-Nirom 1939b). 
means of dissemination of popular music. Modernity, on the radio, had nothing to do with Western artistic modernism - with Stravinsky or Joyce or Mondrian - but everything to do with Western popular entertainment. Thus the opposition of asli and modern in radio discourse of the colonial era is a false antithesis, as is the opposition persisting in twenty-firstcentury Indonesian discourse between traditional and modern music or other arts. The modern can follow from and extend and re-envision the traditional, just as that exceedingly modern - modernistic-music, kebyar, springs from and reformulates the traditional Balinese idioms and repertoires that preceded it. The opposite of the asli or traditional in Indonesia, whether in the 1930s or the 2010s, is not the modern but the popular, which posits radically different frames of reference, aesthetics, functions, and modes of involvement.

\section{Modern Times}

Did radio and gramophone usher their audience into the modern age? In one sense absolutely they did. These media were technologically modern, and they promoted - indeed enforced - modern ways of relating to music: in your home rather than at a celebration; listening to invisible musicians (or, for musicians, performing for an invisible audience); listening, in the case of gramophone records, to performances that could be repeated note for note; listening, if you were a woman, to music that you might not have been allowed or would not have dared to go to hear in person. And, as Jennifer Lindsay points out in the passage I quoted as an epigraph, they 'democratized' the court arts, allowing anyone with access to a radio to listen; moreover, to paraphrase her formulation, by broadcasting the music of specific localities, radio put the local and the modern in dialogue.

But while the medium itself was ineluctably modern and democratic (at least for anyone who could afford a radio), the content was often strongly conservative: witness the many gamelan broadcasts from the court bastions of Javanese tradition, or the tembang Sunda concerts that tethered the 'extras' (panambih) to the classic repertoire and thus restrained them from independence, though (judging from the quantity of gramophone records devoted to them) they were what the public most enjoyed. I think it likely that there was, at least at NIROM, a deliberate effort, a policy, to balance popular with traditional, in order to maximize the audience by appealing to both adults and youth, and also to assert the continuing value of the traditional. This assertion is the burden of the speech by Soetardjo, the director of PPRK, at NIROM's official handover of siaran ketimuran in November 1940: 
In the last century, Eastern culture was greatly influenced, indeed sometimes forced, by Western culture to become modern, advanced and proper [sopan]. Evidently [people] thought that by imitating everything that came from the West they would become advanced and proper [=respectable?]. Among our youth there are not a few who enjoy and value jazz more than the music of the East. It is probably not too much to say that there are also young people who find gamelan and other Eastern music completely alien. For example, they consider the sound of the gamelan boring. If our young people, who will be the seed of our people [=nation?] in the future, do not change their attitude and their direction, I fear that our nation will be disturbed and weakened. 87

Even as it embodied modernity in its medium and in the social relations it facilitated, and even as it promoted what it defined as the modern in its kroncong, Hawaiian, and popular music programs, radio conveyed ambivalence about the modern age. So did other arts and other media gramophone records, theater, popular novels. Lain dahoeloe, lain sekarang (Times change), a radio play broadcast over NIROM in November 1939 by students in Bandung, had the moral, 'be modern if you wish, but don't forget tradition' (modern tinggal modern, akan tetapi adat istiadat djangan ditinggalkan) (Soeara-Nirom 1939e). Another radio play, broadcast over NIROM in August 1938, was titled Gadis modern (Modern girl):

This story will show how a girl comes to ruin because she does not obey the wishes and instruction of her father and instead follows her own wishes and her own opinions. Her father gives her wise advice, but her mother spoils her, and she [the girl] prefers to follow the spirit of the time [kemaoean zaman] rather than heed her father's advice. ${ }^{88}$

87 'Berangkali [sic] disini pada tempatnja, kaloe saja peringetken, bahoea dalem abad jang paling achir ini keboedaja'an Timoer banjak dipengaroei, malahan djoega ada kalanja terdesek oleh keboedaja'an Barat marika mendjadi modern, madjoe dan sopan [sic; garbled?]. Roepanja marika mengira, bahoea meniroe segala sesoeatoe jang dateng dari Barat itoe mendjadi teradjoe atas kemadjoean dan kesopanan marika. Dikalangan pemoeda kita ada malah boleh djadi tida sedikit jang lebih gemar dan menharga [sic] moesik Jazz dari pada mendengerken boenjian-boenjian Ketimoeran. Agaknja tida berlebih-lebihan, djika saja kataken, bahoea ada djoega pemoeda pemoeda kita jang asing sama sekali pada gamelan dan laen boenji boenjian Timoer. Soeara gamelan misalnja katanja membosenken (saai). Kaloe pemoeda kita jang mendjadi bibit ra'jat kita di kamoedian hari, tida merobah sikep dan haloean ini, saja koeatir kebangsa'an kita aken terganggoe dan nistjaja mendjadiken lemahnja (labiel) bangsa kita' (Hong Po 1940).

88 'Tjeritera ini akan menoendjoekkan, bagaimana seorang Gadis telah terdjeroemoes kedalam djoerang 'neraka' oleh karena tiada menoeroet kemaoen [sic] dan pitoeah orang Toeanja, ia menoeroet kemaoeannja sendiri dan menoeroet pendapatannja sendiri sadja. Diberi nasèhat oleh Bapanja, akan tetapi sebaliknja dimandjakan dengan mandja jang salah oleh Iboenja, lebih soeka menoeroet kemaoean zaman dari pada menoeroet nasèhat' (Soeara Nirom 1938c). The play was written by B. Soetan; it may be the same story used by Chang Mung Tze (1939) in the novel Nona modern? (Modern miss?), discussed below. 
These two themes - 'times change' and 'the modern girl' - recur over and over in late-colonial popular culture. They are in fact often melded, since a key example of changing times is that young women no longer behave as they used to: they disobey their parents, refuse arranged marriages, resist limitations on free association (pergaoelan bebas) with the opposite sex. The following song lyric, published in a VORO program guide (Pewarta V.O.R.O. 1936a) under the rubric 'Songs for our young people,' shows the two themes combined:

Doeloe dan sekarang / Then and now

Krontjong-tango - HMV NS 79, issued April 1936

S. Abdullah \& the 'His Master's Voice' Soerabaia Orkest

Nonah-nonah di zaman dahoeloe

Ta' boleh sembarang keloear pintoe

Roepanja alim sangat pemaloe

Apa jang dipikir trada jang tahoe.

Nonah-nonah zaman sekarang

Pandai berias roepanja garang

Soeka bertjanda soeka bergadang

Gila berdansa ta' boleh dilarang.
Young women in the old days

Could not go out of the house at will

In appearance they were pious and very modest

What they were thinking, no one knew.

Young women today

Skillfully put on makeup to look fierce They like to joke and stay out all night They're crazy for dancing and can't be forbidden.

Another lyric, concerned only with the 'modern girl' side of the coin, was published in a catalogue advertising new gramophone records on the HMV label:

Gadis modern / Modern girl

Slowfox Krontjong - HMV NS 477, issued November 1938

Miss Eulis

Gadis moderen ganti pakeannja

Sarong kebaja soeda diboeangnja

Pake rok pande sampai diloetoetnja

Kaloe naek speda kalihatan pahanja.

Atoeran barat selaloe di pakekan

Adat kabangsaan poera2 diloepakan
Modern girls have changed their clothing

They've thrown out their sarongs and kabayas.

They wear short dresses down to their knees

When they ride a bicycle you see their thighs.

They do everything in the Western way

They pretend they've forgotten the traditional ways 
Salam dan hormat soeda di gantikan

Omongan tjara barat, selaloe di goenakan.
They no longer use respectful greetings and speech

The Western way of talking is what they always use.

These songs are arranged as dance tunes (foxtrot, paso doble, rumba, tango) and played by a dance band, and they are broadcast on the radio or played on the gramophone. Both the songs themselves and the media that disseminate them depend on popular music for their appeal and success. Purporting to be critical of modernity, the songs are nevertheless wholly modern in their medium. There are many other such songs. Boeanja pergaoelan (The fruits of [free] association), Gadis djaman sekarang (Girls today), Prampoean dan mode (Women and fashion) are further examples of the 'modern girl' (or 'modern woman') theme, but others range more widely: the world-wide economic depression (Tempo soesah, 'Hard times'); sexual license and exploitation (Malam2 di Tandjoeng Priok, 'Nighttime in Tanjung Priok'; Kepalsoeannja lelaki, 'The dishonesty of men'); the world's violence and cruelty (Boeroeng Koetilang, 'Songbird'; Kekedjaman doenia, 'The harshness of the world'). Some use the Muslim idea of dunia fana, the impermanence of this world and the permanence of the next, to criticize the modern pursuit of pleasure (Djalannja pengidoepan, 'The course of life'; Djalannja doenia, 'The way of the world').

In these songs, the inherent dissonance between their overt content and their presentation negates or trivializes the content: rumbas decrying the rumba. Here is a striking instance of such self-cancellation. It is a twosided gramophone record, one song on each side. On one side is a tango about famine, and on the other a foxtrot about the fun of going on a picnic every week.

\section{Bahaja lapar / The danger of famine}

Tango Krontjong - HMV NS 397, issued May 1938

Gadjali \& the H.M.V. Orchestra

Banjak padi bergoedang goedang

Orang pada tida perdoeli.

When there's lots of rice in the storehouses

No one thinks about it.

Bahaja lapar dateng menjerang

Nasi semangkok berharga sekali.

Brilliant, permata jang dikagoemken

Tra ada jang maoe beli.
When the danger of famine looms

A bowl of rice is very precious.

Gems and jewels that were admired

No one wants to buy them. 
Kaloe soeda begitoe baroe rasaken

Beras dan padi perloe sekali.
Only when things come to this do we realize

That rice is very necessary.

Bikin picnic / Let's make a picnic

Slowfox Krontjong - HMV NS 397, issued May 1938

Gadjali \& the H.M.V. Orchestra

Marih kita orang bersama berdjalan di Let's go on a trip today ini hari

Djangan sampe kaloepahan

Don't forget to bring things to eat. membawak barang makanan.

Marih kita pergi ke kali, kali aernja jang djerni

Di sitoe bikin satoe picnic mentjari kasenengan

Ini picnic ada satoe sport, satoe sport jang baik sekali.

Let's go to the river where the water is clear

There we'll make a picnic and have fun

A picnic is sport, a very good kind of sport.

Bikin kita orang sekalian dapet banjak pengalaman

Maka itoe setiap minggoe sedikitnja moesti sekali

It will give us lots of experiences

So we should do it at least once a week

Pergilah Toean bikin picnic mentjari kasenengan.

Go on, Mister, make a picnic and have fun.

The ambivalence of popular culture towards modernity is understandable, for the modern world posed serious challenges to longstanding Indonesian and Chinese-Indonesian ideas of how to live. Cherished customs and assumptions came under attack. Many of the challenges had to do with women, as 'modern girls' questioned the notions of subservience to their husbands, arranged marriages, and the restriction of their sphere of activity to the home. But modernity in DEI popular music is nothing more than dancing and pleasure (let's make a picnic), and the criticisms of modernity are both formulaic and vapid: modern ways may lead to trouble, and they are Western. (As if the music these songs are couched in were not.)

Popular literature sometimes grappled more seriously with modernity. For example, we see a different notion of the 'modern girl', or, more precisely, of her potential, in a prefatory note that the novelist Liem Khing Hoo, for nine years the editor of the monthly series of pocket novels Tjerita Roman (1929-1941), inserted into the November 1939 issue and signed with his pen-name, Romano. The note again accuses modern girls 
of shallowness, but for once it offers an idea of the constructive possibilities of modernity:

Being modern is not just being good at dancing, taking trips, going to the movies. hanging around with your male friends. There are many things women have not yet worked on: social improvement, increasing their own inner resources and knowledge of the world, improving the economic situation, etc. ${ }^{89}$

The novel this note prefaces is Chang Mung Tze's Nona modern? (Modern miss?), which takes the typical attitude of 1930 novels towards the modern girl. It features a headstrong girl from a wealthy Chinese family in Java (in 'the city of S') who, indulged by her mother, disregards her father's advice and runs away with a charming gambler. Eventually he is revealed as a deceiver who wants her to prostitute herself to cancel his losses. In despair and disgust she poisons herself and him. Although in her carefree life before she meets the gambler she plays piano, drives a car, speaks English, and enjoys dancing and tennis, the author does not blame these modern pursuits for her downfall: her life is destroyed by her refusal to obey her father's restrictions on her association with young men. ${ }^{90}$

Another popular novel, R.A. Moerhia by Njoo Cheong Seng (2005 [1934]), has virtually the same plot situation - conservative father, rebellious (tennis-playing!) daughter - but here the family is Javanese and living in Medan, and the dénouement is different: the daughter marries a Dutchman, who deserts her, returns to Holland, and marries again. In the end she kills herself. (What else can a willful young woman in a ChineseMalay novel do?) Here the central issue is not obedience but rather the accusation by Moerhia's family (who are nationalists) that she is forgetting her Indonesian-ness - forgetting that her skin is dark, her elder brother says - and becoming gila-Blanda (Dutch-crazy). ${ }^{91}$

89 'Sedikit oetjapan: Boeat bisa diseboet modern, boekan tjoema itoe pande dansa, pesiar, nonton bioscoop, galang-goeloeng dengen kawan-kawan lelaki, tapi masih ada banjak hal jang kaoem prempoean belon kerdjaken, seperti: perbaekin sociaal, mempertinggiken tingkatan batin dan pengetaoean hidoep, memperbaekin tingkatan economie d.l.l. [signed] Romano' (in Chang Mung Tze 1939). For Liem Khing Hoo, see Salmon (1981:239).

90 I find this novel interesting because although the author sides with the girl's father, he is willing to show him as cold, rigid, and ultimately vindictive. Until the plunge into melodrama at the end, the novel depicts convincingly the way changing times can thrust people into conflicts they cannot find their way out of.

91 The novel's epigraph is an Indonesian translation of Kipling's famous line beginning, 'East is east and west is west.' 
Nona modern? and R.A. Moerhia exemplify what Claudine Salmon describes as the general ambivalence of pre-war Chinese-Indonesian novels towards modernity (phrased here as Westernization), particularly with regard to the emancipation of women:

Everything suggests that westernization was accepted when it brought with it technical improvements, or improvements in the economy and the realm of daily life, but that it created problems at the cultural level. ... Westernization was considered dangerous when it affected women's status and their role in peranakan society. ... Most of the authors would not resign themselves to accept the effects of Westernization as regards the social position of their wives and daughters. (Salmon 1981:55-6)

The difference between popular music of the 193os and the popular novels of the time is that the novels - those that were not simply sensationalist - were not selling the West at the same time that they disparaged it. In contrast, radio and records in the 1930s got double duty out of modernity, simultaneously promoting it and claiming to deplore it. For media dependent on reaching as wide an audience as possible, this ambivalence, it seems to me, is suspiciously convenient.

\section{References}

Bafagih. 'P.P.R.K. di Volksraad: Soeara-soeara anggota Belanda terhadep P.P.R.K.: Berilah tempo setjoekoepnja kepada P.P.R.K.', Hong Po (Batavia), 7 December, 1940.

Boediardjo, A. 'Eenige opmerkingen over en naar aanleiding van het eerste volksconcert van de "Perserikatan [sic] Perkoempoelan Radio Ketimoeran", Kritiek en Opbouw 4-1:1113, 15 February, 1941 .

—. 'Volksconcert P.P.R.K. jang pertama', Poedjangga Baroe 8-10 (April):252-5, 1941b.

Brandts Buys-Van Zijp, A. 'De eenheidsmuziek', Poedjangga Baroe 9-5 (November):137-9, 1941.

Chang Mung Tze. Nona modern? (Cover-title: Gadis modern...?). Tjerita Roman 11-131 (November), 1939.

Doorn, J. van, A divided society: Segmentation and mediation in late-colonial Indonesia. Rotterdam: Comparative Asian Studies Program, Erasmus University. [Comparative Asian Studies Program 7.] 1983.

Encyclopedie van de muziek. Amsterdam: Elsevier. Two vols, 1956-1957.

Iken, D. and E. Harahap (with revisions by N. Heertjes, 1929) Kitab arti logat Melajoe. Sixth edition, revised by D. Ramaker. Weltevreden: Boekhandel en Drukkerij Visser, 1940.

Indisch verslag. Deel II: Statistisch jaaroverzicht voor Nederlandsch-Indië over het jaar 1938. Batavia: Landsdrukkerij, 1939.

_. Deel II: Statistisch jaaroverzicht voor Nederlandsch-Indië over het jaar 1940. Batavia: Landsdrukkerij, 1941.

Kusbini [=Koesbini]. 'Krontjong Indonesia', Musika: Brosur mengenai ilmu musik dan koreografi 1:19-43, 1972.

Lindsay, J. 'Making waves: Private radio and local identities in Indonesia', Indonesia 64:10523, 1997 .

Mak van Dijk, H. De oostenwind waait naar het westen: Indische componisten, Indische composities, 1898-1945. Leiden: KITLV Uitgeverij, 2007. 
Mangoenkoesoemo, S. 'Z.H. Pang. Ad. Ar. Mangkoe Nagoro VII en de oostersche radio omroep in Ned.-Indië', in: Comité voor het Triwindoe-Gedenkboek (ed.), Het Triwindoe-Gedenkboek Mangkoe Nagoro VII, pp. 181-4. Surakarta: Comité voor het Triwindoe-Gedenkboek, 1939 .

Marle, A. van. 'De groep der Europeanen in Nederlands-Indië, iets over ontstaan en groei', Indonesië 5-3:97-121; 5-4: 314-41; 5-6: 481-507 (September 1951-April 1952), 1951-1952.

Möller, A.J.M. Batavia, a swinging town! Dansorkesten en jazzbands in Batavia, 1922-1949. Den Haag: Moesson, 1987.

Mrázek, R. Engineers of happy land: Technology and nationalism in a colony. Princeton: Princeton University Press. [Princeton Studies in Culture/Power/History], 2002.

Njoo Cheong Seng. R.A. Moerhia: Peringetan Medan 1929-1933. (Cover-title: Raden Adjeng Moerhia). Tjerita Roman 6-66, June 1934. Republished, with modernized spelling, in A.S. Marcus and Yul Hamiyati (eds), Kesastraan Melayu Tionghoa dan kebangsaan Indonesia 9, pp. 109-82. Jakarta: Kepustakaan Populer Gramedia, 2005.

Notosudirdjo, F.S. [=Franki Raden]. 'Music, politics, and the problems of national identity in Indonesia'. PhD dissertation, Madison, WI: University of Wisconsin-Madison, 2001.

Pané, A. 'Kerontjong disamping gamelan', Poedjangga Baroe 8-10 (April):256-6o, 1941a.

-. 'Gamelan tegenover krontjong, droom tegenover werkelijkheid', Poedjangga Baroe 9-1 (July):9-30, 1941b.

Poerbatjaraka and J.S. Brandts Buys. 'Gamelan, grammofoon en radio', Djawa 14-4/5/6 (December): 214, 222, 230, 248-250, 1934.

Resink, G.J. 'Indonesische toekomstmuziek', Kritiek en Opbouw 4-5 (April):74-7, 1941.

Salim, H.A. 'Radio dan masjarakat', Sinar Deli (Medan), 23 and 28 March, 1939.

Salmon, C. Literature in Malay by the Chinese of Indonesia: A provisional bibliography. Paris: Editions de la Maison des Sciences de l'Homme. [Etudes insulindiennes; Archipel 3.] 1981.

Sedjarah radio di Indonesia. Jakarta: Djawatan Radio Republik Indonesia, Kementerian Penerangan, 1953 .

Soetardjo. 'Voorstel tot wijziging van de ordonnantie van 10 september 1930 (Regeling van de vergunning tot het aanleggen van een radio-ontvanginrichting)', Bijlagen der Handelingen van den Volksraad, Zittingsjaar 1936-1937, Onderwerp 109, Stuk 3, submitted 19 November 1936.

SRV gedenkboek. Surakarta: De Solosche Radio Vereeniging. [n.d. - foreword dated 29 August 1936.] 1936.

Statistical pocket book of Indonesia 1941. Batavia: Department of Economic Affairs, Central Bureau of Statistics, 1947.

Statistisch zakboekje voor Nederlandsch-Indië. Batavia: Centraal Kantoor voor de Statistiek, 1934-1938.

Sulaksono, B. 'Perkembangan Solosche Radio Vereeniging di Surakarta tahun 1933-1945'. Thesis, Fakultas Sastra, Universitas Sebelas Maret, Surakarta, 1993.

Sumarsono, T. and E. Garnasih Pirous. Membela kehormatan angklung: Sebuah biografi dan bunga rampai Daeng Soetigna. Bandung: Yayasan Serambi Pirous, 2007.

Takonai, S. 'Soeara NIROM and musical culture in colonial Indonesia'. Ishibashi Makoto, trans. Kyoto Review of Southeast Asia 8/9 (March/October), http://repository.kulib .kyoto-u.ac.jp/dspace/handle/2433/53848, 2007 .

Tsuchiya, K. 'Kartini's image of Java's landscape', East Asian Cultural Studies 25-1-4 (March): 59-86, 1986.

Veur, P.W.J. van der. 'Introduction to a socio-political study of the Eurasians of Indonesia'. PhD dissertation, Cornell University, 1955.

Volkstelling 1930. Deel VIII: Overzicht voor Nederlandsch-Indië. Batavia: Departement van Economische Zaken / Landsdrukkerij, 1936.

VOROJubileum-nummer. Verslag dari Vereeniging voor Oostersche Radio Omroep (V.O.R.O.), tahoen ke satoe (1935). Batavia: VORO, 1936.

Wild, C. 'Indonesia: A nation and its broadcasters', Indonesia Circle 43 (June):15-40, 1987. 
Wiryawan, H. Mangkunegoro VII dan awal penyiaran Indonesia. Surakarta: Lembaga Pers dan Penyiaran Surakarta (LPPS), 2011.

Witte, R. 'Exploitatie en bevoogding: De Europese en inheemse radio-omroep in Nederlands-Indië tot 1942,' Jaarboek mediageschiedenis, 4: Nederlands-Indië: 13-42, 1992.

—. De Indische radio-omroep: Overheidsbeleid en ontwikkeling, 1923-1942. Hilversum: Verloren, 1998.

Yampolsky, P. 'Kroncong revisited: New evidence from old sources', Archipel 79:7-56, 2010.

- 'The record industry in Indonesia/Malaysia/Singapore: The mechanics of an estimate of quantity, 1903-1942', in: Pekka Gronow \& Christiane Hofer (eds), The Lindström project: Contributions to the history of the record industry, vol. 3., pp. 181-212. Vienna: Gesellschaft für Historische Tonträger, 2011.

\section{Radio Program Guides}

Berita VORL. 'Statuten van de Vereeniging voor Oostersche Radio Luisteraars (VORL) di Bandoeng', Berita VORL 4-3 (March):8, 1938a.

—. Berita VORL 4-5 (May):8, 1938 b.

_. 'Jaarverslag bahagian omroep dari VORL tahoen 1938/1939', Berita VORL 5-5 (May):v, 1939 .

De N.I.R.O.M.-Bode. K.W.L. Bezemer, 'Muziek en radio', De N.I.R.O.M.-Bode 1-3 (29 April):34, 1934a.

De N.I.R.O.M.-Bode. 'Oostersche muziek', De N.I.R.O.M.-Bode 1-5 (27 May):1, 1934b.

De N.I.R.O.M.-Bode. 'Uitzendingen ten behoeve van Oostersche luisteraars', De N.I.R.O.M.-Bode 1-8 (8 July):4-5. [Includes Indonesian translation of 1934b.] 1934c.

De Nirom-Bode. 'Het aantal Indische luisteraars', De Nirom-Bode 3-14 (5 April):1, 1936.

_ . 'Programma-samenstelling: Mededeelingen van den Raad van Advies,' De NiromBode 4-36 (5 September):1, 1937 .

Pewarta V.O.R.O. 'Pendahoeloean', Pewarta V.O.R.O 1-1 (6-19 January):1, 1935a.

—. Goenari Wiriodinoto, 'Riwajat V.O.R.O' [Part 1.], Pewarta V.O.R.O. 1-2 (20 January-2 February):(o)-1, 1935b.

- Goenari Wiriodinoto, 'Riwajat V.O.R.O' [Part 3.], Pewarta V.O.R.O. 1-5 (3-16 March):13, 1935c.

. 'Menambah njanjian akan pemoeda-pemoeda kita', Pewarta V.O.R.O. 2-9 (26 April-9 May):2, 1936a.

- .2-16 (2-15 August), 1936b.

- 2-19 (13-26 September):2, 1936c.

_ _. A.R. [=Abdoelrachman Saleh], 'Permoelaan kata', Pewarta V.O.R.O. 3-1 (20-31 January):1-2, 1937a.

C. A.R. [=Abdoelrachman Saleh], 'Kiriman dari studio', Pewarta V.O.R.O. $3^{-6}$ (1-15 April):1-2, 1937b.

C.M.A. [=? S.M. Alaydroes], 'Tjoeatja baroe: Pengharapan boeat di hari kelak', Pewarta V.O.R.O. 3-12 (1-15 July):1, 1937c.

_ . A.R. [=Abdoelrachman Saleh],'Tentang pengiriman dari Studio Voro', Pewarta V.O.R.O. 3-18 (1-15 October):1, $1937 \mathrm{~d}$.

—. 'Verslag pendek dari Vereniging voor Oosterse Radio Omroep (V.O.R.O.) 1937', Pewarta V.O.R.O. 4-5 (1-15 March):1-3, 1938.

—. 'Verslag pendek', Pewarta V.O.R.O. 5-6 (16-31 March):1, 1939a.

_ _ 'Staat dari penerimaan dan pengeloearan oewang 1938', Pewarta V.O.R.O. $5^{-7}$ (1-15 April):5, 1939 . 
Soeara Nirom. 'Programma-Archipel. Centraal oentoek Bandoeng dan Batavia', Soeara Nirom 4-1 (1-15 January):6-7, 1937a.

—. 'Succes-Nirom', Soeara Nirom 4-2 (16-31 January):4, 1937b.

. 'Berita Nirom', Soeara Nirom 4-17 (22 Augustus-4 September):4-5, 1937c.

—. 'Pemberitahoean daripada Raad van Advies tentang Siaran Radio Nirom', Soeara

Nirom 4-17 (22 August-4 September):5-6, 1937d.

_. 'Taman kesenian', Soeara Nirom 4-23 (14-27 November):4-5, $1937 \mathrm{e}$.

—. 'Siratoer' rohmi', Soeara Nirom 4-24 (28 November-11 December):4-9, 1937 f.

Soeara Nirom 5-1 (9-22 January):9, 1938a.

_. 'Taman kesenian', Soeara Nirom 5-4 (20 February-5 March):5-6, 1938 b.

—. 'Taman sandiwara', Soeara Nirom 5-15 (24 July-6 August):6, 1938c.

_. 'Taman kesenian', Soeara Nirom 6-6 (19-31 March):7-9, 1939 a.

Soeara-Nirom. 'Berita Nirom', Soeara-Nirom 6-12 (11-24 June):2-3, $1939 \mathrm{~b}$.

. 'Taman kesenian', Soeara-Nirom 6-16 (6-19 August):4, 1939c.

—_. 'Taman kesenian', Soeara-Nirom 6-22 (22 October-11 November):2-3, 1939d.

—. 'Taman kesenian', Soeara-Nirom 6-23 (12-25 November):4, $1939 \mathrm{e}$.

_. 'Taman kesenian', Soeara-Nirom 6-24 (26 November-9 December):2-3, 1939 .

_. 'Taman kesenian', Soeara-Nirom 7-1 (7 January):2-3, 1940a.

_ . 'Taman kesenian', Soeara-Nirom 7-3 (21 January):2-3, 1940 ob.

—. 'Taman kesenian', Soeara-Nirom 7-7 (18 February):2-3, 1940c.

—. 'Taman boenga Nirom', Soeara-Nirom 7-15 (14 April):1, 1940d.

—. 'Programma siaran-timoer Nirom', Soeara-Nirom 7-29 (21 July):1, 1940 .

—. 'Jang penting seminggoe ini!', Soeara-Nirom 7-32 (11 August):2-3, $1940 \mathrm{of}$.

—. 'Jang penting seminggoe ini!', Soeara-Nirom 7-34 (25 Augustus):4-5, 1940g.

—. 'Jang penting seminggoe ini!', Soeara-Nirom 7-36 (8 September):2-3, $1940 \mathrm{~h}$.

—. 'Pemoeda kita dan radio', Soeara-Nirom 7-39 (29 September):1, 1940i.

Soeara Timoer: Madjallah P.P.R.K. Hamid Algadrie, 'P.P.R.K. dan keboedajaan Indonesia', Soeara Timoer 1-1 (28 [recte 29] December 1940-11 January 1941):2, 1940-1941.

. Soetardjo. 'Pidato Ketoea P.P.R.K. Toean M. Soetardjo pada pemboekaän malam

"Kesenian Timoer" di Stadsschouwburg, pada tanggal 11 Januari 1941', Soeara Timoer 1-3 (26 January):2, 1941.

—. 'Poesparagam', Soeara Timoer 2-2 (8 February):1, 1942.

\section{Newspaper articles (unsigned)}

Darmo-Kondo (Surakarta). 'Solosche Radio Vereeniging', Darmo-Kondo, 31 January, 1934a. [Fourth and final installment of 'Solosche Radio Vereeniging: Pemboekaan officieel oleh bestuur', which begins in the issue of 26 January 1934.]

_ . 'Solosche Radio-Vereeniging: Pidato dari voorzitter toean Ir. R.M. Sarsito pada tg. 1. April 1934 dimoeka micropoon', Darmo-Kondo, 3 April, 1934b.

Hong Po (Batavia). 'Pidatonja toean M. Soetardjo: Penjiaran radio berarti menanem dan mengidoepken keboedaja'an Timoer. Toedjoeannja P.P.R.K.: Goena kemadjoeannja bangsa Timoer di Indonesia', Hong Po, 6 November, 1940.

Persamaan (Padang). 'Bagaimanakah perhoeboengan P.P.R.K. dengan Nirom?', Persamaan, 9 September, 1940.

Pewarta Soerabaia (Surabaya). 'Lagi Oostersche omroep', Pewarta Soerabaia, 14 November, 1938a.

- 'Lagoe-lagoe timoer dan penoeroenan omroep-bijdrage', Pewarta Soerabaia, 3 December, 1938 b.

‥ 'Kenapa penjiaran P.P.R.K. djelek', Pewarta Soerabaia, 25 November, $1940 a$. 
— _ 'Soerat kiriman: P.P.R.K. dan penjiaran Nirom', Pewarta Soerabaia, 29 November, $1940 b$.

. 'Soerat terboeka: P.P.R.K. roesoeh?', Pewarta Soerabaia, 18 December, $1940 c$.

. 'Siaran P.P.R.K. dalem tiga boelan: Apakah P.P.R.K. mampoe mengatoer siaran katimoeran?', Pewarta Soerabaia, 30 January, 1941a.

— _ 'Protest terhadep P.P.R.K. mendapet reactie', Pewarta Soerabaia, 6 June, 1941b.

Sinar Pasoendan (Bandung). 'Plaat gramofoon revolutionair', Sinar Pasoendan, 27 January, 1937a.

—_. 'Plaat gramofoon revolutionair tea', Sinar Pasoendan, 29 January, 1937b.

Sin Tit Po (Surabaya). 'Rapat oemoem dari radio-bezitters', Sin Tit Po, zo August, 1938.

Soeara 'Oemoem (Surabaya). 'Nirom dan pendengar bangsa Tionghoa: haroes diadakan Nirom III', Soeara 'Oemoem, 22 March, 1939. 